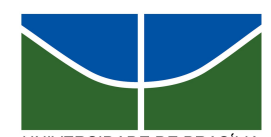

UNIVERSIDADE DE BRASÍLIA

Centro de Excelência em Turismo

Pós-graduação Lato Sensu

Curso de Especialização em Formação de Professores em Turismo

\title{
A INSERÇÃO DA DISCIPLINA TURISMO COMO TEMA TRANSVERSAL NO ENSINO MÉDIO DO MUNICÍPIO DE PARATY: UMA URGÊNCIA SOCIAL.
}

Sidney de Sousa Alves Sineiro

Brasília - 2009 


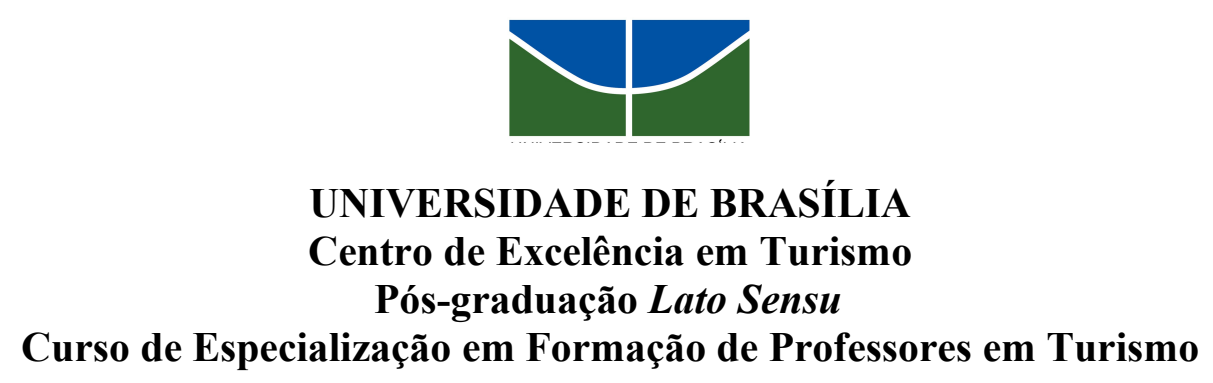

\section{A INSERÇÃO DA DISCIPLINA TURISMO COMO TEMA TRANSVERSAL NO ENSINO MÉDIO DO MUNICÍPIO DE PARATY: UMA URGÊNCIA SOCIAL.}

Sidney de Sousa Alves Sineiro

Monografia apresentada ao Centro de Excelência em Turismo - CET, da Universidade de Brasília - UnB, como requisito parcial à obtenção do grau de Especialista em Turismo sob a orientação da Dra Márcia Elizabeth Bortone.

Brasília - 2009 
Sineiro, Sidney.

A inserção da disciplina turismo como tema transversal no ensino médio do município de Paraty: uma urgência social / Sidney de Sousa Alves Sineiro - Brasília, 2009.

xvi, 64 f.: il.

Monografia (especialização) - Universidade de Brasília, Centro de Excelência em Turismo, 2009.

Orientadora: Márcia Elizabeth Bortone.

1. Turismo. 2. Educação. 3. Identidade. 4. Brasil. I. Título. II. Título: uma revisão. 
UNIVERSIDADE DE BRASÍLIA

Centro de Excelência em Turismo

Pós-graduação Lato Sensu

Curso de Especialização em Formação de Professores em Turismo

\section{A INSERÇÃO DA DISCIPLINA TURISMO COMO TEMA TRANSVERSAL NO ENSINO MÉDIO DO MUNICÍPIO DE PARATY: UMA URGÊNCIA SOCIAL.}

Sidney de Sousa Alves Sineiro

Examinado por:

Dra. Márcia Elizabeth Bortone

Professora orientadora

Ph.D Maria de Fátima Guerra de Sousa

Professora examinadora

Brasília, 22 de Maio de 2009. 


\section{DEDICATÓRIA}

Dedico esta humilde contribuição a todos que acreditam na capacidade do turismo em despertar nas pessoas um novo significado para a atividade. É a oportunidade de entender "o diferente' e incentivar atitudes de maior respeito frente a tudo e todos que partilham o mesmo planeta. 


\section{AGRADECIMENTOS}

Agradeço sempre a Deus por esta oportunidade de viver em uma família tão especial quanto a minha, onde meus pais sempre me ensinaram acima de tudo a honestidade e o respeito ao próximo.

Parte deste trabalho é fruto do meu irmão, Dedé, pela paciência com as ilustrações e por todo carinho dedicado em toda este tempo.

Devo este trabalho também a minha amada e futura esposa, Sabrina, que me apoiou nas horas difíceis e sempre me entendeu.

Não posso me esquecer das companheiras Fabrini e Eny que compartilharam dúvidas e soluções em muitos fóruns, não deixando esfriar esta oportunidade impar.

Ao pessoal do CET, especialmente o Thiago e o Gleison, pela dedicação, companheirismo e paciência em todo este curso. Agradeço a professora Márcia pela sua experiência e auxilio no amadurecer das idéias.

Como parte integrante da pesquisa, agradeço o carinho das direções dos três colégios municipais de Paraty que prontamente se colocaram a disposição para fornecer os alunos e os professores para os questionários. Ao pessoal da AVT-BR que me atenderem de forma cortes e fornecerem total apoio.

A todos que trilharam comigo nos fóruns e no encontro presencial meu muito obrigado! 


\section{EPÍGRAFE}

"Não é possível refazer este país, democratizá-lo, humanizá-lo, torná-lo sério, com adolescentes brincando de matar gente, ofendendo a vida, destruindo o sonho, inviabilizando o amor.

Se a educação sozinha não transformar a sociedade, sem ela tampouco a sociedade muda."

Paulo Freire 


\section{RESUMO}

O presente trabalho aborda como a inserção da disciplina turismo como tema transversal na grade do ensino médio de Paraty pode ser uma valiosa ferramenta na aprendizagem educacional e os alunos tracem novas relações com a atividade que representa quase $80 \%$ de toda atividade econômica do município.

O trabalho se justifica pela necessidade dos alunos conhecerem melhor seus bens naturais e culturais, a fim de lutarem pela preservação, divulgação ao longo do tempo e estabelecerem uma relação mais profunda com os turistas. A atividade turística pode contribuir para a preservação do patrimônio cultural e material e ser um instrumento de ensino muito eficaz para os turistas e os moradores.

Palavras-chave: Patrimônio, educação, identidade e preservação. 


\begin{abstract}
The present work approaches as the insertion of discipline tourism as transversal subject in the grating of the average education of Paraty can be a valuable tool in the educational learning and the pupils trace new relations with the activity that almost represents $80 \%$ of all economic activity of the city.

The work is justified by the necessity for the pupils to know their natural and cultural patrimony better, in order to fight for the preservation, spread along the time and they establish a more deep relation with the tourists. The tourist activity can contribute for the preservation of the cultural and material patrimony and be an instrument of very efficient teaching for the tourists and the residents.
\end{abstract}

Key words: Patrimony, education, identity and preservation. 


\section{LISTA DE ABREVIATURA E SIGLAS}

AVT- BR - Agência de Viagens e Turismo;

EMBRATUR - Instituto Brasileiro de Turismo;

IBGE - Instituto Brasileiro de Geografia e Estatística;

IPHAN - Instituto do Patrimônio Histórico Artístico e Nacional;

LDB - Lei de Diretrizes e Bases da Educação Nacional;

MEC - Ministério da Educação;

MTUR - Ministério do Turismo;

PCN - Parâmetros Curriculares Nacionais;

PNT - Plano Nacional de Turismo;

SENAC - Serviço Nacional de Aprendizagem Comercial;

UNESCO - Organização das Nações Unidas para a educação, a ciência e a cultura. 


\section{SUMÁRIO}

1 INTRODUÇÃ̃O

2 O TURISMO NA SOCIEDADE E NAS INSTITUIÇÕES DE ENSINO............ 14

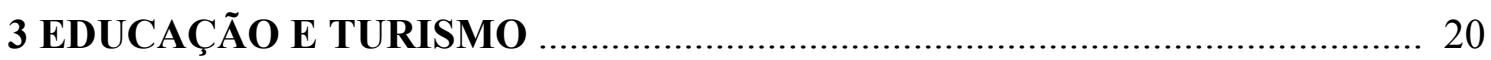

3.1 PARÂMETROS CURRICULARES NACIONAIS - PCN....................................22

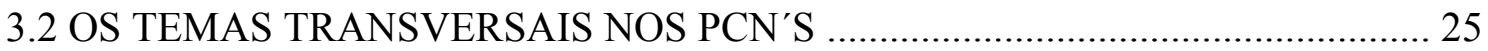

3.3 A QUESTÃO DA INTER E DA TRANSDISCIPLINARIDADE ......................... 27

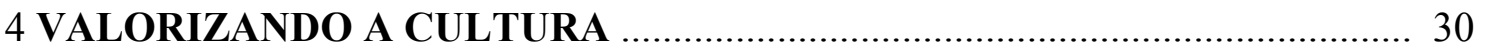

4.1 EDUCAÇÃO PATRIMONIAL ….............................................................. 30

4.2 PLANEJAMENTO INTERPRETATIVO _..................................................... 34

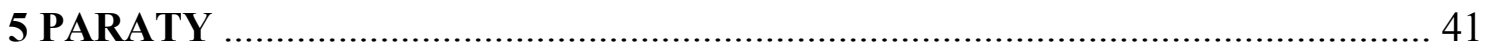

5.1 A EDUCAÇÃO TURÍSTICA EM PARATY .................................................. 42

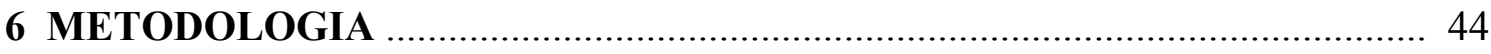

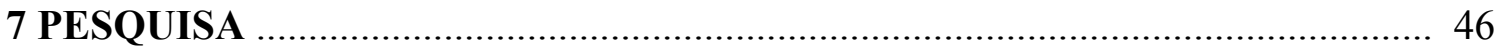

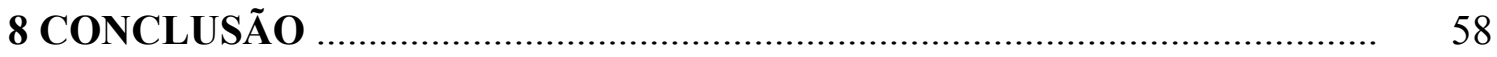

REFERÊNCIAS BIBLIOGRÁFICAS E OUTRAS …..................................... 60

APÊNDICE 


\section{1 - INTRODUÇÃO}

O turismo vem ganhando crescente espaço na sociedade moderna representando importante oportunidade de negócio para inúmeros locais em todas as partes do globo e uma das principais formas de lazer.

Seu desenvolvimento em muitos destinos ainda, infelizmente, ocorre sem um planejamento integrado a comunidade, deixando para segundo plano a preocupação com toda a riqueza cultural e natural, que realmente justificam a atividade turística no local.

A monografia se justifica pela análise da pertinência da disciplina turismo, como tema transversal no ensino médio, contribuir para um novo olhar dos alunos paratienses perante a atividade turística, que atualmente é responsável por quase $80 \%$ de toda atividade econômica local. É a oportunidade para que os alunos conheçam, compreendam, respeitem e divulguem de melhor forma toda a riqueza cultural e natural, que encanta turistas de todas as partes do mundo.

$\mathrm{Na}$ primeira parte do trabalho há uma análise do desenvolvimento da atividade turística nas últimas décadas e quais os fatores que corroboraram para se tornar uma das principais forças econômicas mundiais. A partir disto, há descrição de quando e como a atividade turística passou a ter uma abordagem metodológica no mundo e um panorama das ações nacionais ao longo do tempo a fim de divulgar e buscar maior compreensão do turismo nas escolas e nas universidades.

As diretrizes legais que norteiam o ensino escolar são abordadas na segunda parte, demonstrando a possibilidade do turismo ser trabalhado como algo transversal as disciplinas tradicionais, contribuindo para superar o modelo de ensino fragmentado, que dificulta a compreensão e maior participação dos alunos com as questões globais. 
Algumas ações para valorizar a cultura e integrar os alunos do ensino médio de Paraty aos seus bens materiais e imaterias são tratados na parte terceira parte, contribuindo para que superem a simples visão de elementos contemplativos.

No quinto capítulo a escolha da cidade de Paraty como um dos 65 destinos indutores do desenvolvimento turístico nacional evidencia a necessidade de uma abordagem mais profunda na cidade de Paraty. Algo que é observado no sétimo capítulo pela grande maioria dos alunos e professores do ensino médio do município, com a pesquisa realizada.

O principal objetivo deste trabalho é demonstrar que a inserção da disciplina turismo como tema transversal na grade curricular é a oportunidade da atividade turística continuar representando importante atividade no município, visto que os alunos passariam a adotar novas atitudes com o seu patrimônio, com suas contribuições como cidadão e conseqüentemente nas suas relações com os turistas. 


\section{O TURISMO NA SOCIEDADE E NAS INSTITUIÇÕES DE ENSINO}

A atividade turística vem ganhando, especialmente nas últimas duas décadas, crescente espaço na economia mundial, tornando-se importante fonte de renda e empregos para inúmeras localidades além de uma das principais formas de lazer.

Seu desenvolvimento foi possibilitado por uma série de alterações na estrutura global, como:

- Ampliação dos direitos trabalhistas como o direito a férias remuneradas, licenças de serviço, feriados prolongados e aposentadorias precoces;

- A globalização de mercados internacionais;

- Estabilização econômica de muitos países;

- Diversificação das formas de trabalho;

- Desenvolvimento e a disseminação de novas tecnologias - transportes mais eficientes e a comunicação facilitada de modo que aluguel de carros, passagens em vários tipos de transporte e reservas em diversos tipos de hospedagem pudessem ser oferecidos a partir de um simples comando em terminais de computador;

- Abertura de novas áreas de turismo (Europa oriental, China, sudeste asiático etc.);

- Os meios de comunicação de massa e até a cultura de massa, presentes na sociedade, são permanentes convites e estímulos às viagens, seja para entretenimento, cultura, repouso, além de outras modalidades como comerciais e profissionais;

- Aumento da expectativa de vida. De acordo com o IBGE (Instituto Brasileiro de Geografia e Estatística), através do documento Projeção da População do Brasil por Sexo e Idade, a população brasileira alcançou a média de 72 anos em 2008. Com isso as pessoas dispõem de um tempo maior para viagens e lazer.

- O mundo inteiro oferece possibilidades de contatos humanos mais fáceis, uma vez que a variedade cultural propicia tipos de intercâmbios mais diversos e, com isso, maiores são as possibilidades de agradar a variedade de gostos, dos mais sofisticados aos mais exóticos;

- O desgaste do cotidiano, provocado pelo stress das grandes metrópoles, leva as pessoas a procurarem formas de sentir sossego, tranqüilidade, paz. Com isso, há uma busca pela aproximação com a natureza;

- A vida moderna e o exercício profissional, cada vez mais exigente, levam as pessoas a viverem cada vez mais distantes de suas residências e de suas famílias, aumentando as 
viagens de curta duração. Um dado recente que comprova tal fato no país é o levantamento feito pelo Ministério do Turismo - Mtur, em 2008, onde a demanda por pacotes domésticos teve um aumento médio de $20 \%$.

$\mathrm{Na}$ medida em que as pessoas descobriram o turismo, os investimentos empresariais acompanharam esta demanda, construindo novos atrativos turísticos, formulando novos roteiros, desenvolvendo formas mais velozes de deslocamento e segmentando os públicos de acordo com o perfil. Neste grande avanço, a preocupação com a qualificação da mão de obra tornou-se uma exigência competitiva, especialmente pela maior grau de exigência dos clientes e pelos inúmeros casos de destinos turísticos que não obtiveram êxito pela falta de conhecimento técnico de seus planejadores. Com isto as empresas vêm buscando constantes investimentos em cursos profissionalizantes a seus funcionários, seja através de cursos técnicos para a área operacional ou cursos superiores em turismo e hotelaria para a área de planejamento.

Infelizmente, o "debate turístico" ainda está muito restrito aos meios acadêmicos, aos órgãos públicos formadores das políticas públicas e de forma ainda muito tímida aos cursos profissionalizantes, o que precisa ser alterado, visto que a atividade turística é uma realidade na vida de praticamente todas as pessoas, seja de forma direta ou indireta.

É necessária, inicialmente, uma explicação mais profunda às pessoas sobre o que é turismo, quais são seus impactos e seus limites para que possam compreender e participar de forma ativa deste processo crítico que ainda é muito recente no país e no resto do mundo.

Vivemos uma época onde o turismo passou a ser umas das principais forças transformadoras do mundo e apesar disso "[..] a atividade ainda não deixou de ser encarada como setor menor da economia produtiva. E, em virtude desse entendimento estrábico, o fenômeno turístico, por conseguinte, é precariamente compreendido no Brasil.” (BENI, 2004, p. 9). 
A pesquisa na área ainda é muito recente e os primeiros estudos tratando das noções de turismo, na literatura, são da década de 1870 onde os trabalhos se concentravam nos impactos econômicos e geográficos do turismo na Alemanha. Nos anos 20 o país ainda estava na vanguarda dos estudos, com a criação do centro de Pesquisas Turísticas na Universidade de Berlim, onde seus membros estavam principalmente preocupados em estudar e entender os aspectos econômicos do turismo.

Aos poucos os estudos foram aprofundando em âmbito internacional e a partir das décadas de 60 e 70 os estudos em turismo passaram a aparecer com freqüência na bibliografia especializada, principalmente nas áreas sociais.

Apesar de ser uma prática antiga em toda a sociedade

só aparece como área cientifica de estudos recentemente, e sua evolução foi notável, levando-se em conta o curto período de sua ocorrência. Mesmo considerando que importantes bases de seus estudos foram assentadas antes da Segunda Guerra Mundial, seu desenvolvimento cientifico só ocorreu após a mesma. (REJOWSKI, 2003, p. 17)

Gradativamente, o debate sobre a atividade turística ganha espaço em todo o globo e os EUA representam a maior referência para a comunidade internacional, com uma crescente comunidade de pesquisadores que promovem constantes eventos de caráter técnico cientifico como congressos, simpósios, seminários, reuniões, etc a fim de discutir a atividade turística sobre as mais diversas visões.

No Brasil, o surgimento da educação em turismo teve início na década de 50 através do Serviço Nacional de Aprendizagem Comercial - SENAC que desenvolveu uma educação instrumental, voltada para a operacionalização de hotéis e restaurantes. Ao longo dos anos a atividade ganhava força e na década de 70 houve o início do estudo do turismo no meio acadêmico, especialmente por muitos creditarem à atividade turística a possibilidade de desenvolvimento econômico de forma praticamente instantânea. 
O primeiro curso brasileiro de turismo iniciou-se em 1971 na Faculdade de Turismo do Morumbi (atualmente Anhembi-Morumbi) na cidade de São Paulo. A partir deste momento novos cursos superiores foram surgindo como da Faculdade Ibero-Americana de Letras e Ciências Humanas, em 1973 em São Paulo e da Faculdade da Cidade, em 1974, no Rio de Janeiro.

$\mathrm{Na}$ década de 80 novos cursos superiores em turismo continuaram surgindo, como o Instituto Newton Paiva, em 1980, na cidade de Belo Horizonte, a Faculdade de Turismo da Bahia, na cidade de Salvador em 1984 e a Faculdade de Ciências Sociais Aplicadas, em 1985, em Foz do Iguaçu.

A partir da década de 90 houve um aumento considerável de cursos nesta área, graças a crescente demanda de mercado, com o desafio de formar profissionais para o trade comprometidos com o bem estar social. O ensino de turismo também ganhou destaque nas escolas básicas, onde tinha o objetivo de levar um conhecimento aos alunos do ensino médio e fundamental sobre a atividade, que vivia momentos de euforia em diversos países.

O governo federal, através do Instituto Brasileiro de Turismo - EMBRATUR, desenvolveu programas como Iniciação Escolar para o Turismo e o Programa Embarque Nessa. Este último contou com o apoio do SENAC e procurou demonstrar os benefícios que a atividade turística poderia propiciar à população local, além de mostrar a possibilidade de ser acessível a todas as classes sociais.

Outra ação que ganhou destaque foi o programa Aprendiz de Turismo desenvolvido pela Agência de Viagens e Turismo - AVT - Br que propagava conhecimento sobre turismo à alunos do ensino fundamental e médio em escolas públicas.

O programa Embarque Nessa: Turismo, cultura e cidadania também fez parte das ações governamentais e tinha por objetivo formar multiplicadores do turismo dentro da 
sociedade,despertar nos jovens o cuidado com o patrimônio e conscientizar os estudantes sobre a geração de renda provocada pela atividade turística.

Recentemente a AVT- Br, em parceira com o Mtur e o Núcleo de Turismo da Universidade de São Paulo - NT/USP desenvolveram o programa Caminhos do Futuro, composto por nove apostilas que

mostram caminhos e a importância de se desenvolver o turismo de forma sustentável e inclusiva, gerando renda e benefícios para todos os brasileiros. O desafio é capacitar professores em conteúdos de turismo,para que absorvam novos conhecimentos e despertem nas crianças e jovens o interesse pela conservação do patrimônio natural e cultural e também pelas carreiras emergentes no mercado do turismo. (GUIA, 2007 apud ALMEIDA, 2007, p. 3)

O material didático é distribuído aos parceiros associados do projeto e apesar de não ser profissionalizante, há uma preocupação com o mercado de trabalho com módulos de português, inglês e espanhol instrumental.

O projeto está inserido nas diretrizes do PNT (Plano Nacional de Turismo), que reconhece e valoriza parcerias para o desenvolvimento do setor.

A partir do avanço nos estudos sobre a atividade turística a nível internacional e do processo de amadurecimento do país com a criação de programas para aproximar o turismo dos alunos, ainda que de forma desorganizada graças a descontinuidade das políticas públicas, o momento atual oferece excelente oportunidade para levar o conhecimento e o debate turístico ao âmbito local.

O objetivo desse estudo é propor a inserção da disciplina turismo na grade curricular do ensino médio do município de Paraty, aliada ao PCN - Parâmetros Curriculares Nacionais - como tema transversal.

Sua inserção é a possibilidade dos alunos apresentarem uma maior compreensão sobre o fenômeno turístico - seus limites, suas possibilidades - e principalmente despertar o interesse sobre a cultura local, seus bens materiais e imateriais num processo de alfabetização 
cultural. Com isto o turismo passa a ser pensado por todos, em um processo de afirmações e negativas, que deve ser uma preocupação de todas as pessoas do município. 


\section{3 - EDUCAÇÃO E TURISMO}

Antes de tratarmos da relação entre educação e turismo, é primordial definir essas palavras. Apesar de o turismo ter inúmeras definições, muitas são marcadas por uma visão muito disciplinar como aquelas propostas pela economia e geografia.

Do nosso ponto de vista, uma definição adequada de turismo é a de Andrade:

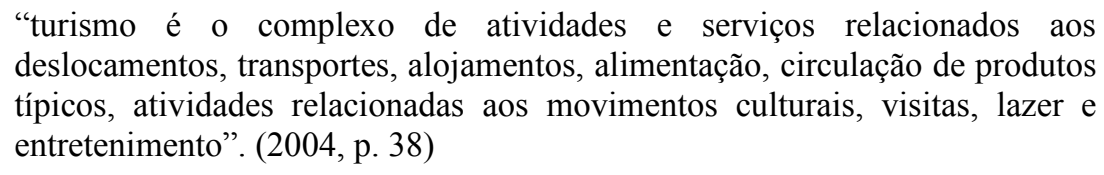
deslocamentos, transportes, alojamentos, alimentação, circulação de produtos típicos, atividades relacionadas aos movimentos culturais, visitas, lazer e entretenimento". (2004, p. 38)

Vê-se assim a enorme abrangência do fenômeno turístico e variedade de relações econômicas nele envolvidas. Sem o contato pessoal não há possibilidades destas ocorrerem, de tal modo que "[..] esta atividade alcance projeção eminentemente humana, acima das conseqüências econômicas e comerciais" (Dias, 2003, p. 35).

De uma forma resumida, turismo é o estudo dos movimentos e das relações estabelecidas pelos indivíduos fora do seu local de residência.

Já educação, segundo Delors (1999, p. 12), é “um processo permanente de enriquecimento, do saber-fazer, mas também e talvez em primeiro lugar, como via privilegiada de construção da própria pessoa, das relações entre indivíduos, grupos e nações". Esta definição mostra a complexidade desse processo já que deve considerar o sujeito. A educação vai muito além de simplesmente apresentar um conteúdo. Segundo Freire (2002, p. 12)

$$
\begin{aligned}
& \text { é preciso, sobretudo, [..] que o formando, desde o principio mesmo de sua } \\
& \text { experiência formadora, assumindo-se como sujeito também da produção do } \\
& \text { saber, se convença definitivamente de que ensinar não é transferir } \\
& \text { conhecimento, mas criar as possibilidades para a sua produção e construção". }
\end{aligned}
$$

Educar, ensinar e aprender são processos que se relacionam entre si. Para nenhum deles há fórmula mágica, até porque são processos contínuos marcados por novas questões e soluções a todo tempo. 
Ao se ensinar, uma das principais preocupações deveria ser a de despertar no aluno um sentimento investigativo, capaz de levá-lo a desejar o "conhecer-além". Essa idéia se encontra na apresentação dos Parâmetros Curriculares Nacionais - PCN (MEC, 2000, p. 5), onde se reconhece a necessidade do "desenvolvimento da capacidade de pesquisar, buscar informações, analisá-las e selecioná-las; a capacidade de aprender, criar, formular, ao invés de simples exercício de memorização".

Atualmente o processo educacional e, em especial, o de ensino, se caracteriza pela fragmentação de conteúdos. Em decorrência disso os alunos deixam de visualizar as disciplinas como algo macro, composto de diversos elementos que as influenciam diretamente. Perde-se, assim, a visão do todo.

Para Bernardi (2009):

[..] alguns processos de ensino e aprendizagem adotados pelos educadores não são suficientes para explicar às crianças e jovens as complexidades econômicas, políticas, morais, religiosas em uma sociedade globalizada. Em razão disso formam-se verdadeiras ilhas entre os vários campos do conhecimento e contextos globais. (BERNARDI, http://www.futuroeventos.com.br/noticias/main/integra?noticia_id=389)

Esta ilha de conhecimentos, através da fragmentação, fez que os alunos passassem a adquirir e armazenar conhecimentos em uma área de interesse, deixando para segundo plano os outros pontos que também fazem parte do contexto estudado. Toda esta fragmentação gerou a hiperespecialização que

impede de ver o global (que ela fragmenta em parcelas) bem como o essencial (que ela dilui). Ora, os problemas essenciais nunca são parceláveis, e os problemas globais são cada vez mais essenciais. Além disso, todos os problemas particulares só podem ser posicionados e pensados corretamente em seus contextos; e o próprio contexto desses problemas deve ser posicionado, cada vez mais, no contexto planetário.” (MORIN, 2003, p. 13).

Nenhuma ciência ou área do conhecimento consegue sozinha, explicar a vida, o homem e o mundo. Exemplo disto é a questão ambiental em um município, onde a compreensão apoiada apenas pela ciência e geografia não é suficiente para se entender todo o 
processo. Há, indubitavelmente, o auxílio de conhecimentos históricos, das Ciências Naturais, da Sociologia, da Demografia, da Economia entre outras para possibilitar esta compreensão.

No estudo do fenômeno turístico isto também é comum. As diversas disciplinas que o estudam limitam os estudos a seus campos de atuações, o que impede o aprofundamento dos debates sobre seus impactos, por não levar em consideração que um destino turístico não é formado apenas por um patrimônio, por relações comerciais, números de empregados e sim, composto pela inter-relação entre pessoas e serviços que possibilitam a formação de determinado produto turístico.

O processo educacional precisa ir além da formação profissional, simplesmente gerador de mão de obra, e possibilitar uma visão maior, uma atitude investigativa. A atividade turística, presente em praticamente na vida de todas as pessoas pode contribuir para esta troca de experiências entre o "nosso" e o "dos outros", onde o entendimento e a interação são capazes de contribuir para uma nova forma de lidar com o patrimônio material, imaterial e com o desenvolvimento humano.

\section{1 - Parâmetros Curriculares Nacionais - PCN}

OS Parâmetros Curriculares Nacionais foram elaborados pelo Ministério da Educação - MEC em 1997, sendo aplicados a partir de 1998. Desde então, passaram a ser referências nacionais para o processo educacional em todas as regiões do país. Eles têm norteado as políticas educacionais. Seu objetivo maior é despertar o interesse pelos alunos para uma maior participação, reflexão e autonomia, de forma a serem conhecedores de seus direitos e deveres na sociedade em que vivem.

Os PCNs, que podem ser aplicados aos alunos do $1^{\circ}$ ao $8^{\circ}$ ciclo $\left(1^{\mathrm{a}}\right.$ a $8^{\mathrm{a}}$ série $)$ e atualmente aos alunos do Ensino Médio, possuem um conteúdo flexível que possibilita uma adaptação a realidade de cada região, com isto abre-se caminho para: 
- Um despertar nos alunos do sentimento de cidadania (pertencentes a um país, um local) conhecendo suas características sociais, materiais e culturais;

- Conhecer e valorizar a pluralidade do patrimônio sociocultural, bem como aspectos socioculturais de outros povos e nações. A medida que o conhecimento for se aprofundando contribui para diminuir os sentimentos de discriminação ainda tão comuns na sociedade;

- Perceber - se como um ser agente transformador do ambiente, com seu papel integrante na sociedade;

- Questionar a realidade, formulando-se problemas e tratando de resolvê-los, utilizando pensamento lógico, criatividade e capacidade crítica.

Os parâmetros podem inspirar os professores a criarem estratégias inovadoras de ensino, indo além da monotonia do quadro negro, do simples conhecimento das disciplinas convencionais, pois como um aluno poderá compreender a grandeza da terra se não tem pleno conhecimento do próprio local onde mora, da própria identidade? Com isto

$$
\begin{aligned}
& \text { [..] ao inserir questões que possibilitam a compreensão e a critica da } \\
& \text { realidade, ao invés de tratá-los como dados abstratos a serem aprendidos } \\
& \text { apenas para passar de ano, oferece aos alunos a oportunidade de se } \\
& \text { apropriarem deles como instrumentos para refletir e mudar a própria vida.” } \\
& \text { (MEC/SEF, 1998, p. 23) }
\end{aligned}
$$

A abertura aos temas locais e regionais nos PCN's, permite a inserção de outros temas, visto que “[...] não exclui a possibilidade e a necessidade de que as redes estaduais e municipais, e mesmo as escolas, acrescentem outros temas relevantes à sua realidade." (PCN, p. 26) . E é sobre esta possibilidade e necessidade que a disciplina turismo enriqueceria o debate sobre a compreensão da realidade social, dos direitos e das responsabilidades dos alunos (futuros cidadãos participantes dos processos decisórios) no município de Paraty, já que a cidade é um dos mais importantes destinos turísticos nacionais.

A escola é o local ideal para as reflexões sobre a localidade pois:

- É onde alunos de diferentes origens e costumes podem conviver em um constante intercâmbio de experiências;

- É onde as regras dos espaços públicos são ensinadas, mostrando (pelo menos em tese) que todos possuem direitos e deveres perante a sociedade; 
- Por apresentar conhecimentos sistematizados sobre o país e o mundo, ela possibilita um desejo investigativo, com debates e discussões sobre temas comuns a todas as nações;

- As ações desenvolvidas na escola podem (e devem) repercutir através de um círculo que pode gerar excelentes resultados, ampliando o entendimento e a compreensão da sociedade por todos, da seguinte forma:

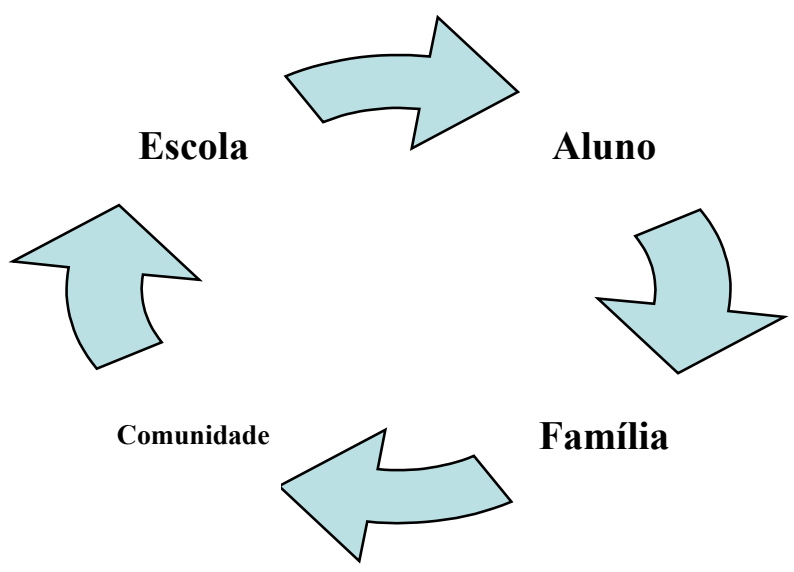

É no período do ensino médio, que a disciplina turismo pode apresentar melhores resultados, visto que os alunos já possuem uma base de conhecimentos que pode ser enriquecida com um aprendizado mais aprofundado sobre a cultura, o patrimônio cultural, natural do município de Paraty. Tal disciplina pode, ainda, ser uma grande aliada no processo de aprendizagem de outras como geografia, economia, sociologia que direta ou indiretamente, estão envolvidas ou têm impactos nas atividades turísticas. Outro fator que justifica a inclusão da disciplina turismo no ensino médio é o citado pelo artigo 35 da Lei de Diretrizes e Bases LDB com relação a finalidade do ensino médio:

a) A consolidação e o aprofundamento dos conhecimentos adquiridos no ensino fundamental, possibilitando o prosseguimento de estudos;

b) A preparação básica para o trabalho e a cidadania do educando, para continuar aprendendo;

c) $\mathrm{O}$ aprimoramento do educando, incluindo a formação ética e o desenvolvimento da autonomia intelectual e do pensamento crítico;

d) A compreensão dos fundamentos científico-tecnológicos dos processos produtivos. 
A inserção da disciplina turismo como tema transversal, é uma ótima oportunidade para alcançar os objetivos acima propostos, visto que abre espaços para a realidade do município e, ao mesmo tempo, pode contribuir para a formação, para o trabalho e para a sua responsabilidade como cidadão.

Segundo os Parâmetros Curriculares Nacionais

a escola não muda a sociedade, mas pode, partilhando esse projeto,com outros segmentos sociais que assumem os princípios democráticos, articulando-se a eles, constituir-se não apenas como espaço de reprodução mas também como espaço de transformação. (MEC/SEF, 1998, p. 23)

Desta forma percebe-se que as transformações na sociedade ocorrem a partir de uma série de âmbitos, como econômico, político e cultural, sendo a educação fator primordial neste processo.

\section{2 - Os Temas Transversais nos PCN's}

Na lei $n^{\circ} 9.346 / 96$, há uma abertura no sentido de cada escola possa se organizar de tal forma a propiciar a uma educação de qualidade. Uma valiosa ferramenta para maior qualidade no aprendizado foi a inserção dos temas transversais nas escolas para aproximar o conhecimento das matérias tradicionais a partir de experiências dos alunos. Tais temas se distribuem em 5 eixos temáticos: Ética, meio ambiente, pluralidade cultural, orientação sexual, trabalho e consumo. Seu surgimento deveu-se a:

[..] questionamentos realizados por alguns grupos politicamente organizados em vários países sobre o qual deve ser o papel da escola dentro de uma sociedade plural e globalizada e sobre quais dever ser os conteúdos abordados nessa escola." (ARAÚJO,1999, apud FILHO, 2007, p. 110).

Os temas transversais não criam novas disciplinas. Devem ser incorporados nas disciplinas escolares, de modo a ultrapassar os limites das disciplinas, e ampliar o entendimento de temas que vão além do objeto estudado. Como exemplo, a visita a uma praia do município de Paraty pode ser a possibilidade de ensinar aos alunos conteúdos sobre biologia, geografia e até mesmo levantar discussões sobre o lixo gerado por moradores e 
turistas. Do mesmo modo, eles podem tratar de outras questões presentes nas vidas dos alunos e da sociedade, ainda não explorados no campo educacional, mostrando os múltiplos aspectos e diferentes dimensões das questões humanas e naturais.

$\mathrm{Na}$ escolha desses temas a escola pode nortear-se pelos mesmos critérios usados pelos Parâmetros Curriculares Nacionais: Urgência social, abrangência nacional e favorecimento da compreensão da realidade e a participação social.

Ao inserir o Turismo como tema transversal, os professores podem mostrar as relações entre as disciplinas comuns, ensinadas nas escolas e presentes na vida de todos, e o fenômeno turístico. Ao se planejar uma viagem a determinado destino, por exemplo, o aluno poderá utilizar seus conhecimentos geográficos, históricos, matemáticos e até mesmo de outro idioma no destino, colocando-os em prática no seu cotidiano.

Este é um exemplo de como o turismo está presente na vida das pessoas em simples coisas do dia a dia. Muitas delas nem percebem isso, inclusive, vêem ele como algo muito complexo e acessível a poucas pessoas. Uma nova interpretação pode complementar e maximizar a compreensão correta sobre outras disciplinas como história, biologia, geografia e outras.

As cidades que já possuem fluxos turísticos e aquelas que apresentam possibilidade para este desenvolvimento apresentam forte potencial para se trabalhar temas como meio ambiente, pluralidade cultural e ética, visando ao desenvolvimento de uma consciência cidadã que pode até mesmo ser utilizada a favor da atividade turística.

Como a globalização ganhou espaço até nos locais mais remotos, as pessoas sofrem influências de todas as partes do mundo. Nesse processo, os alunos são constantemente estimulados por novas formas de comunicação, praticamente em todos os locais e

[..] o educador não pode ignorar que as pessoas são influenciadas pelos meios de comunicação de massa e pelo contato pessoal feito nestes locais. Nos espaços pós-industriais, reais ou virtuais, encontram-se pessoas e empresas especializadas em comunicação e entretenimento. Ai podem veicular seus 
produtos e suas idéias, possibilitando as pessoas um aprendizado diferenciado e divertido." (TRIGO, 2002, p.149).

Assim sendo, a interação entre o cotidiano do aluno e o conteúdo a ser ensinado deve ser preocupação constante da escola. No caso do ensino médio de Paraty o currículo pode ser enriquecido por meio de apresentações de danças, música, fotografia, artesanato e artes em gerais. Essas atividades, que compõem toda a riqueza cultural, possibilitam aos alunos apresentarem suas histórias, suas culturas aos professores, aos outros alunos (uma vez a área territorial ser extensa, o que dificulta o conhecimento mais aprofundado) e até mesmo à sociedade.

Como a pluralidade cultural é um tema transversal abre-se uma valiosa oportunidade para que todos possam se conhecer melhor, o que desperta e aumenta o nível de conhecimento. Essa idéia está bem fundamentada nos Parâmetros Curriculares Nacionais, ao mostrar a importância de se

fortalecer a cultura de cada grupo social, cultural e étnico que compõe a sociedade brasileira, promover seu reconhecimento, valorização e conhecimento mútuo, é fortalecer a igualdade, a justiça, a liberdade, o diálogo e, portanto, a democracia. (MEC/SEF, 1998, p. 132)

Desta forma, o conhecimento possibilita uma reflexão mais investigativa sobre toda a história local, com um maior compromisso, capaz de levar a novas atitudes, refletindo-se na relação com o meio ambiente e na melhoria da qualidade de vida.

\section{3 - A Questão da Inter e da Transdisciplinaridade}

A proposta de temas transversais ampliou a possibilidade de inserir temas do cotidiano. Isso contribuiu para que o ensino pudesse ter uma abordagem mais local, aprofundada e integrada entre as disciplinas convencionais, em uma visão inter e transdisciplinar.

As definições de inter e transdisciplinaridade ganharam enorme destaque a partir dos anos 60, principalmente na França e Itália, contra a alienação das instituições de ensino às 
questões relacionadas com a estrutura curricular altamente especializada e enviesada em uma única direção, a lógica do capitalismo.

Atualmente as duas definições ainda não são compreendidas corretamente, sendo consideradas em muitos casos apenas sinônimos.

Para uma conceituação adequada, a interdisciplinaridade

deverá então entender-se qualquer forma de combinação entre duas ou mais disciplinas com vista à compreensão de um objecto a partir da confluência de pontos de vistas diferentes e tendo como objecto final a elaboração de uma síntese relativamente ao objecto comum. (POMBO, 1994, p. 13, grifo nosso)

Já a transdisciplinaridade

é o nível máximo de integração disciplinar que seria possível alcançar num sistema de ensino. Tratar-se-ia então da unificação de duas ou mais disciplinas tendo por base a explicitação dos seus fundamentos comuns, a construção de uma linguagem comum, a identificação de estruturas e mecanismos comuns de compreensão do real, a formulação de uma visão unitária e sistemática de um sector mais ou menos alargado do saber."

(POMBO, 1994, p. 13, grifo nosso)

De acordo com Carlos (2007, p. 37), as definições podem ser ilustradas da seguinte forma:

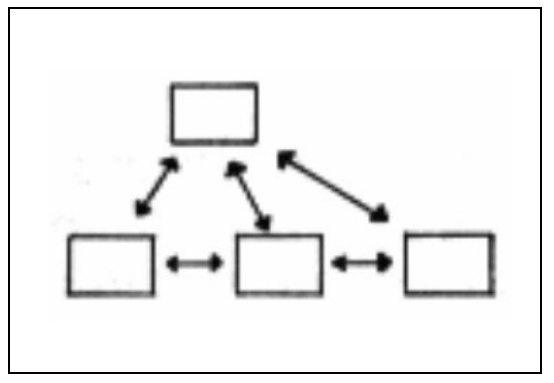

Interdisciplinaridade

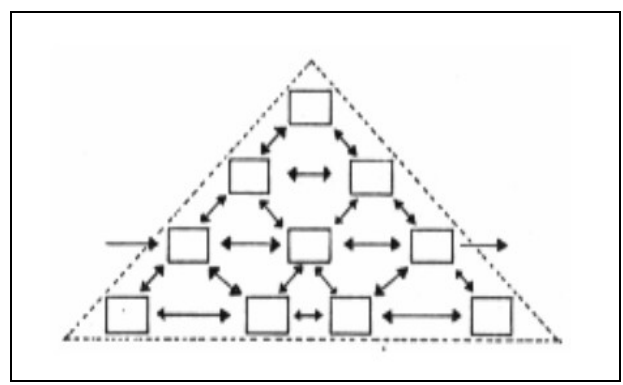

Transdisciplinaridade

De forma geral, a interdisciplinaridade pode ser considerada como a união de alguns elementos de diversas disciplinas para enriquecer e facilitar o aprendizado de determinado conteúdo.Como por exemplo, a explicação de determinada parte da historia brasileira, onde o professor leva para sala de aula outras informações e fatos da época como aspectos culturais, antropológicos e geográficos. Este tipo de atitude pro ativa do professor complementa o 
aprendizado sobre novos aspectos e pode despertar novos questionamentos por parte dos alunos.

A transdisciplinaridade vai além, pois tem como ponto de partida um desafio ou problema e, auxiliada por diversos campos de conhecimento, procura chegar a uma solução, ou seja, busca uma compreensão holística dos fatos e das coisas e é neste processo que a atividade turística se insere.

Para Rejowski

O turismo está passando por um processo de "cientificidade" já ocorrido em outras áreas do conhecimento, que indica a existência de pequena, mas crescente comunidade de pesquisadores oriundos principalmente das áreas sociais. É um promissor campo de estudo do acadêmico e sua plena compreensão envolve um sem número de disciplinas.” (REJOWSKI, 2003, p. 109)

Este processo já ocorreu em outras áreas e é primordial um consenso de conceitos básicos e métodos de pesquisa para estabelecer questões orientadoras na produção e reprodução do conhecimento na área. Para Trigo, o ensino em turismo

\footnotetext{
não se pode trabalhar sem um nível de integração profundo e coerência interna entre as diversas disciplinas que compõem os diversos programas de turismo. Não basta, por exemplo, uma interação apenas multidisciplinar (diversas disciplinas enfocando um problema ou desafio) ou interdisciplinar (integração de conceitos e idéias como aspectos fundamentais)." (TRIGO, 2002, p. 158).
}

A interdisciplinaridade e transdisciplinaridade não anulam a identidade das disciplinas, mas as complementam. Deixa-se, assim, de se ter uma visão fragmentada do conhecimento e de se passar isto para os alunos.

Toda a variedade de disciplinas e a integração dessas com os temas transversais enrique as inúmeras possibilidades de diferentes abordagens que o fenômeno turístico pode ser estudado, maximizando assim, a compreensão desse fenômeno cada vez mais presente na vida das pessoas. 


\section{4 - VALORIZANDO A CULTURA LOCAL}

A cidade de Paraty já percebeu a importância da preservação de seus bens materiais e imateriais buscando desenvolver a atividade turística de forma sustentável, que de acordo com Murta e Albano (2005, p. 16) "[...] deve-se voltar para harmonizar as necessidades de seus quatro componentes: a comunidade receptora, os visitantes, o meio ambiente e a própria atividade turística". Esta premissa de sustentabilidade é um desafio comum em inúmeras cidades turísticas, já que as oportunidades de lucros a curto prazo ainda seduz em muitas comunidades e empreendedores. O desenvolvimento sustentável é a garantia da existência da riqueza cultural e natural, por conseguinte da atividade turística ao longo do tempo.

A busca por despertar o interesse das pessoas sobre a importância da própria cultura e o entendimento de outras é algo que precisa ser vivenciado nas escolas, sendo o ensino médio uma ótima oportunidade, e este conhecimento pode ser passado das mais variadas formas, entre elas estão a educação patrimonial e o planejamento interpretativo como poderosos instrumentos de valorização da cultura.

\subsection{Educação Patrimonial}

Inspirada no trabalho pedagógico desenvolvido na Inglaterra sob a designação de Heritage Education, a proposta da educação patrimonial foi trazida para o Brasil em 1983 e é uma valiosa ferramenta para a descoberta e valorização do patrimônio cultural, visto que a cultura fornece a base para a construção da identidade e cidadania dos indivíduos em uma determinada sociedade.

De acordo com Horta $(1999$, p.6)

a educação patrimonial é um instrumento de 'alfabetização cultural' que possibilita ao individuo fazer a leitura do mundo que o rodeia, levando-o a compreensão do universo sociocultural e da trajetória histórico-temporal em que está inserido. 
O despertar da consciência cultural é fundamental para a população do município, visto que só assim as pessoas (adultos e crianças) usufruirão melhor de seus bens, buscarão compreender e divulgar sua identidade e conhecer a cultura de outros povos. Todos esses fatores contribuem para a construção da identidade e a interação entre as pessoas.

A necessidade de educar as pessoas para que elas possam ter uma atitude mais crítica e preservacionista perante o meio em que vivem já era defendida no Brasil por Mário de Andrade da década de 20 com o movimento modernista, sendo que a educação crítica deveria ser iniciada junto com o processo de escolarização. Com isto o ensino não seria simplesmente informar e sim formar. "Dentro desta perspectiva, o educando não deve ser considerado, pura e simplesmente, como massa a ser informada, mas sim como sujeito, capaz de construir-se a si mesmo, através da atividade, desenvolvendo seus sentidos, entendimentos, inteligências etc.” (LUCKESI,1993, p.118).

Como Paraty possui uma riqueza material e imaterial ímpar, um conhecimento mais aprofundado por parte dos alunos pode refletir positivamente no turismo já que quando as pessoas conhecem sua identidade e sentem-se parte do local tornam-se mais seguras, o que contribui para que sejam mais hospitaleiras e capacitadas para passar um conhecimento verdadeiro aos turistas. O que vai ao encontro dos verdadeiros objetivos do turismo cultural: adquirir conhecimentos sobre o local visitado, ter uma relação com a comunidade muito além do simples contato entre prestador de serviços e consumidor e refletir sobre o seu cotidiano a partir do conhecimento de outras culturas.

Para Horta $(1999$, p. 8) a alfabetização cultural

consiste em provocar situações de aprendizado sobre o processo cultural e seus produtos e manifestações, que despertem nos alunos o interesse em resolver questões significativas para sua própria vida, pessoal e coletiva.

Conseqüentemente, as atitudes da comunidade e dos turistas em valorizar o patrimônio irão muito mais além do que simples respeito aos monumentos públicos. A educação patrimonial permite resgatar a memória e os valores que originalmente levaram a localidade 
considerar um personagem, um lugar, um objeto ou um prédio como um patrimônio da coletividade.

A metodologia aplicada à educação patrimonial se desenvolve em 04 etapas:

\section{Tabela 01}

\section{Etapas da metodologia da Educação Patrimonial}

\begin{tabular}{|l|l|l|}
\hline \multicolumn{1}{|c|}{ Etapas } & \multicolumn{1}{|c|}{ Recursos/ Atividades } & \multicolumn{1}{c|}{ Objetivos } \\
\hline 1) Observação & $\begin{array}{l}\text { Exercício de percepção visual/sensorial, } \\
\text { por meio de perguntas, manipulação, } \\
\text { experimentação, mediação, anotações, } \\
\text { comparaça, dedução, jogos de } \\
\text { detetive... }\end{array}$ & $\begin{array}{l}\text { - Identificação do objeto/ } \\
\text { - Desenvolvimento da percepção visual e } \\
\text { simbólica. }\end{array}$ \\
\hline 2) Registro & $\begin{array}{l}\text { Desenhos, descrição verbal ou escrita, } \\
\text { gráficos, fotografias, maquetes, mapas e } \\
\text { plantas baixas. }\end{array}$ & $\begin{array}{l}\text { - Fixação do conhecimento percebido, } \\
\text { aprofundamento da observação e análise } \\
\text {-Desenvolvimento da } \\
\text { pensamento lógico, intuitivo } \\
\text { operacional. }\end{array}$ \\
\hline 3) Exploração & $\begin{array}{l}\text { Análise do problema, levantamento de } \\
\text { hipóteses, discussão, questionamento, } \\
\text { avaliação, pesquisa em outras fontes } \\
\text { como bibliotecas, arquivos, cartórios, } \\
\text { instituições, jornais, entrevistas. }\end{array}$ & $\begin{array}{l}\text { Desenvolvimento das capacidades de } \\
\text { análise e julgamento crítico, interpretação } \\
\text { das evidencias e significados. }\end{array}$ \\
\hline 4) Apropriação & $\begin{array}{l}\text { Recriação, releitura, dramatização, } \\
\text { interpretação em diferentes meios de } \\
\text { expressão como pintura, escultura, } \\
\text { drama, dança, música, poesia, texto, } \\
\text { filme e vídeo. }\end{array}$ & $\begin{array}{l}\text { Envolvimento afetivo, internalização, } \\
\text { desenvolvimento da capacidade de auto- } \\
\text { expanaro, apropriação, } \\
\text { criativa, valorização do bem cultural. }\end{array}$ \\
\hline
\end{tabular}

Fonte: Horta, Maria; p. 11, 1999

Esta metodologia possibilita aos alunos de Paraty e até mesmo os turistas estabelecerem uma relação mais próxima e real entre os conceitos ensinados e o bem patrimonial como um todo.

O Museu Imperial, localizado em Petrópolis, utiliza o método de educação patrimonial desde os anos 80 e tem o Projeto Dom Ratão como um exemplo muito bem sucedido, aplicado até o presente. O projeto foi elaborado visando atender às classes de pré-escolar e alfabetização (2 a 6 anos) como uma introdução ao vivenciamento do museu, sendo desenvolvida em três etapas sucessivas: o teatro de fantoches, a visita ao Palácio e atividades de registro e exploração. Isto demonstra a possibilidade de aproximar os alunos de sua história, de forma bem lúdica, desde os primeiros anos o que leva a um aproveitamento melhor de seus bens, incentiva a busca por maior conhecimento e certamente terá reflexos nas 
suas atitudes como cidadãos. A cidade de Paraty tem uma incrível diversidade que ainda não foi utilizada corretamente pelos professores. Atualmente algumas escolas de São Paulo e do Rio de Janeiro já praticam turismo educacional na região, ação que ainda é muito tímida nas escolas do município.

Em São Miguel, Rio Grande do Sul, a educação patrimonial tem sido desenvolvida desde 1987 em parceria entre comunidade local, universidades, associações de amigos, iniciativa privada e os governos municipais e estaduais. As ações têm contribuído de forma direta para a facilitação do entendimento sobre a importância histórica e a necessidade de valorização e preservação por parte das comunidades que habitam os sítios arqueológicos missioneiros do Brasil (São Miguel Arcanjo, São Nicolau, São João Batista e São Lourenço Mártir). Há oficinas para crianças da $5^{\circ}$ série com uma visita guiada ao sítio arqueológico com a exibição de um vídeo. Em um segundo momento as crianças partem para uma experiência concreta, simulando o trabalho de arqueólogo, onde as crianças coletam, limpam, classificam e montam os materiais encontrados na superfície. È comum que algumas crianças devolvam pequenos fragmentos de cerâmicas recolhidos durante a visita inicial, demonstrando a efetividade do método da educação patrimonial na mudança de atitude em relação ao patrimônio cultural.

$\mathrm{Na}$ cidade de São Luis (MA), famosa por suas casas revestidas de azulejos portugueses, a parceria entre prefeitura e Ministério da cultura criou o programa Monumenta. O objetivo do projeto é preparar mão de obra qualificada e facilitar a inserção dos jovens no mercado de trabalho. Durante os três meses do projeto, o aluno aprende a história da cidade e do azulejo e tem aulas práticas de restauração nos próprios prédios. Isto mostra a variedade de formas de transmitir conhecimento, gerar renda e ainda restaurar patrimônios, que podem ser utilizados na criação de novos atrativos turísticos. 
Paraty tem um amplo acervo à disposição da educação patrimonial e do turismo, que aliados tem muito a contribuir para o desenvolvimento e a preservação local, como:

- A pesca local que vem se tornando um atrativo graças a aumento gradual dos turistas que desejam um contato maior com todas as particularidades do município. Esta pode incentivar aos turistas atitudes mais responsáveis com os manguezais e o respeito ao defeso de algumas espécies em certas épocas do ano. Este tema também pode ganhar destaque nas aulas;

- A culinária local que já é incentivada nos restaurantes e precisa ser levada as escolas, por dois fatores: Garantir a pratica ao longo do tempo com produtos locais e incentivar a prática alimentar saudável, frente a imposição de alguns ingredientes e sabores em todas as partes do mundo, que apresentam péssimo valor nutricional;

- A riqueza ambiental, com a Mata Atlântica que ocupa $80 \%$ do município, é um convite a descoberta dos atrativos naturais e que, bem trabalhada, é uma ótima forma de conscientizar para a população local e os turistas para que despertem para a importância de preservar a mata, rios e animais;

- As visitas guiadas as igrejas, casarões e em todos os pontos turísticos servem para ilustrar as aulas, em um contato muito mais interessante, capaz de despertar o lado lúdico dos alunos e dos turistas. Sem dúvida é uma forma muito mais prazerosa de conhecer toda a história local.

\section{2 - Planejamento Interpretativo}

Com a crescente divulgação e crescimento da atividade turística em todos os cantos do mundo, muitos destinos têm buscado oferecer boa infra-estrutura de hospedagem, transportes e alimentação e alguns serviços que "ocupem" o turista durante a sua estada, como simples passeios próximos ao meio de hospedagem. Todavia isto é muito pouco frente ao enorme patrimônio que o município de Paraty dispõe para a visitação, e, se bem planejados, pode acrescentar valor à experiência turística. E um importante aliado neste processo é o 
planejamento interpretativo, que segundo Murta e Albano (2005, p. 13) “é o processo de acrescentar valor à experiência do visitante, por meio do fornecimento de informações e representações que realcem a história e as características culturais e ambientais de um lugar”.

No Brasil, tão vasto em patrimônios e em manifestações culturais, infelizmente, ainda são isoladas as ações de experiência de interpretação do patrimônio. Todavia o assunto vem ganhando destaque com publicações especializadas através de profundo estudo sobre seus resultados.

O tema foi proposto pela primeira vez, na década de 50, nos EUA, por Freeman Tilden, que buscou sensibilizar os visitantes do Parque de Yosemite e do Grand Canyon para a importância da preservação ambiental.

$\mathrm{Na}$ década de 60, a proposta de acrescentar valores aos turistas durante a experiência turística ganhou presença na Grã-Bretanha, buscando a valorização de importantes áreas naturais.

A partir da década de 80 , a interpretação se tornou parceira na criação de atrações turísticas e culturais por toda Europa, como diferentes tipos de museus, centros culturais, centro de visitação e informação.

Em 1999, realizou-se na Inglaterra a conferência internacional "Apresentação e Interpretação do Patrimônio na Europa", onde ficou claro que os padrões de desenvolvimento e comportamentos vivenciados em diversos países estavam sendo mais destrutivos que preservacionistas, onde

a única chance de reverter esse quadro que temos hoje é trazendo a preservação para o coração e a mente das pessoas, lidar com suas emoções de forma a desenvolver nelas afeição pelo ambiente que as circunda, pelo espaço público, pela natureza, pela vida silvestre e por sítios históricos(MURTA e GOODEY, 2005, p. 17).

O processo da interpretação patrimonial, seja ela em um patrimônio cultural ou natural, precisa ser desenvolvida baseada em alguns princípios, onde se deve: 
- Iniciar a interpretação em parceria com a comunidade, sendo importante forma de trocar conhecimentos e recursos;

- Sempre focalizar os sentidos dos visitantes, de forma a estabelecer a conscientização pessoal sobre determinadas características do ambiente;

- Utilizar muitas artes visuais e de animação a fim de estimular a curiosidade do visitante, encorajando-o a buscar um conhecimento mais aprofundado sobre o que está sendo interpretado;

- Ser acessível ao público o mais amplo possível, tendo o seu planejamento a preocupação em inserir os portadores de necessidades especiais;

- Ter uma abordagem abrangente, que seja capaz de ligar os temas do passado, do presente e do futuro dimensionando todos os fatores socioeconômicos que influenciaram a história do lugar.

Para Murta e Albano (2005,p.19)

o planejamento da interpretação orienta a limpeza e a descoberta de fachadas originais; a harmonia da sinalização e do desenho de placas e letreiros compatíveis com o 'espírito' do lugar; as trilhas pela malha urbana que 'decifram' a cidade e as placas informativas que ampliam a percepção ambiental do visitante. Também no âmbito dos museus e casas históricas, a interpretação, realizada com o uso de sedutoras técnicas interativas, amplia a compreensão popular sobre sítios e coleções históricas.

Exemplos deste planejamento que orientaram o desenvolvimento de atrativos turísticos que valorizam fachadas tradicionais de uma comunidade ocorreu na Costa do Sauípe - BA e acabaram despertando o interesse dos moradores da região em manter seu estilo arquitetônico tradicional, visto que é algo diferente da cultura dos turistas e estes buscam o "diferente" ao visitar um local.

Durante o levantamento dos bens que possuem a capacidade de ser um atrativo turístico é de suma importância o conhecimento de toda a história local já que há todo um contexto envolvido na criação daquele bem e que pode até contribuir para a melhor adequação 
da mídia a ser utilizada na interpretação. Isto pode ser alcançado com a pesquisa muito bem fundamentada em fontes idôneas, livros e artigos científicos e principalmente em depoimentos da população autóctone, que conhece melhor que ninguém a história do lugar e pode ajudar na recriação de fatos vividos.

O plano interpretativo em um determinado destino deve ser constituído de 03 etapas essenciais:

- Inventário e registro de recursos, temas e mercados - Onde se levanta todos os recursos culturais, ambientais, técnicos e financeiros que a localidade dispõe e quais serão necessários para atingir o público-alvo.

- Desenho e montagem - Após a definição do público - alvo e os recursos disponíveis, é a fase de se escolherem os meios e as técnicas que serão utilizadas, sendo baseados em três questões: o que os turistas devem saber? O que devem sentir? Quais as atitudes desejadas?

- Gestão e promoção - A gestão garantirá a preservação e atualização das instalações interpretadas, através da manutenção e avaliação permanente e treinamento da equipe. A publicidade deve ser focada para o público específico, através da utilização de folhetos, painéis, mapas, guias ilustrativos, tv e rádio. Uma interessante forma de divulgar um lugar e que cada vez mais ganha impulso é a promoção de celebrações no destino, como festivais, eventos dos mais variados gêneros, de acordo com o perfil do público e da localidade; acabam enriquecendo a vida social e movimentam a economia local. Durante a gestão e promoção do atrativo, é importante ter informações precisas quanto à questão dos horários de visitação, da qualidade do acesso, preço e da infra-estrutura para que o turista se oriente e planeje suas atividades da melhor forma. Até mesmo porque muitos turistas só se preocupam em buscar cultura no horário comercial e alguns atrativos podem ter seus horários de visita bem restritos ou flexíveis. As informações gerais sobre os atrativos podem ser muito bem veiculadas também com a ajuda da internet, já que o acesso a esta ferramenta de informação é crescente. 
No local, a estratégia utilizada para a interpretação do bem cultural variará de acordo com as características locais, recursos financeiros e humanos disponíveis e do perfil do público. Exemplos que vêm sendo muito bem utilizados são trilhas e roteiros sinalizados em cidades ou regiões turísticas, guias impressos e acompanhantes, mapas, folders e centro de informações.

A cidade de Paraty apresenta um grande potencial para o desenvolvimento desta sinalização, que poderia ser estabelecida através de parcerias entre as escolas e o governo. Este tipo de atitude incentivaria a participação ativa dos alunos, como o material a ser utilizado, o lay-out dos materiais e outros debates que enriquecem o aprendizado sobre o local e possibilitam a abordagem de novos conteúdos em sala de sala.

Passando para uma análise mais profunda sobre o planejamento interpretativo, vale um destaque para os meios e as técnicas de interpretação, já que estes podem influenciar de forma negativa e positiva a experiência turística no local.

Para Murta e Albano (2005, p. 24) os meios de interpretação estão agrupados em três grandes categorias: interpretação ao vivo, textos e publicações e a interpretação com base no design.

A interpretação ao vivo é vivenciada com o auxilio de um guia ou ator contanto casos e "causos" do local, encenando, cantando, conversando, demonstrando exemplos materiais e imateriais e ilustrando temas e processos locais aos visitantes. Pode ser feita a pé, de bicicleta, a cavalo ou utilizando algum meio de transporte que permita o deslocamento entre a área visitada. É uma forma de ensino que apresenta grande eficácia quando se quer expressar a essência e dar vida a um lugar. Exemplo desta interpretação acontece no Museu Industrial de Ironbridge, Inglaterra, onde vários atores vestidos como artesãos e comerciantes da Revolução Industrial vendem mercadorias na moeda da época. Em Paraty está representação ainda é 
muito tímida frente ao potencial de gerar empregos à população e maior conhecimento sobre importante parte da história brasileira, até mesmo para os turistas.

A segunda categoria, textos e publicações servem como importantes complementos a informações transmitidas através de exibições e servem como guia pessoal ao visitante. Os mais tradicionais são os mapas ilustrados, guias e roteiros, folders e cartões postais.

Dependendo da qualidade do material impresso, ele contribuirá para a publicidade dos atrativos e até mesmo um souvenir a ser levado para casa. Como os alunos possuem grande criatividade, concursos para a elaboração de desenhos para os mapas, folders e cartões postais é uma excelente chance para exercitar o lado lúdico dos alunos e até mesmo buscar maiores informações sobre determinado patrimônio.

A interpretação com base no design, terceira categoria, vem sendo cada vez mais utilizada como forma de apresentar o patrimônio natural e cultural de cidades, parques e centros culturais. Ela é mais ampla, sendo agrupadas em meios estáticos e meios animados de interpretação.

Os meios estáticos de exibição não incluem nenhuma participação do turista, limitando-o apenas na visualização e apreciação. São representados através de placas, painéis, letreiros, exposição de objetos e documentos e em modelos e reconstruções como as miniaturas, as cópias em escala real, as maquetes e os dioramas.

Os meios de exibição animados são aqueles que buscam auxilio nos instrumentos mecânicos e eletro-eletrônicos para acrescentar realismo e tornarem a comunicação com o visitante mais eficaz. Possuem várias formas de representação, como a utilização de guias sonoros portáteis, painéis iluminados, apresentações de slides e documentários guiados pelos turistas e o uso de movimento. O município de Paraty possui tradicionais alambiques com potencial para ir além da simples visita de degustação da cachaça. Podem demonstrar e permitir a participação dos visitantes de todo o processo de fabricação e um debate sobre o 
uso do solo, as formas de lidar com a cana e ao mesmo tempo contar um pouco da historia local, para turistas e moradores.

Os meios animados têm sido amplamente utilizados por museus, centros culturais e parques temáticos. Por se tratarem de uma forma de exibição que possibilita a interação de adultos e crianças tem alcançado um grande sucesso na forma de ensinar, já que de forma lúdica os temas e as mensagens acabam sendo transmitidas e absorvidas.

Conclui-se que a atividade turística é uma interessante forma de quebrar o clima "frio", aproximando as pessoas de toda a sua cultura, memória e identidade.

Um fator que pode ser um grande diferencial para as ações que buscarão despertar a consciência crítica e de responsabilidade sobre a cultura paratiense é a possibilidade de criar ações que não precisem construir novos atrativos ou utilizar muitos recursos financeiros para contar a profunda relação entre os seres humanos e a cultura.

A educação patrimonial tem muito a contribuir neste processo, pois é uma fonte direta de conhecimento e compreensão do passado e presente e deve ser valorizada e incentivada de forma bem abrangente aos vários níveis da sociedade, afim de que a população do município perceba,valorize e lute pela preservação de todo o seu patrimônio cultural e natural.

O planejamento interpretativo é uma possibilidade de gerar conhecimento e proximidade maior entre o local visitado e visitante, devendo ser desenvolvida de forma criativa, para que supere a monotonia de alguns atrativos turísticos que infelizmente até o presente desperdiçam a chance se aproximar os turistas e a população local das características culturais em um debate de novas descobertas. 


\section{5 - PARATY}

A cidade de Paraty possui uma riqueza patrimonial que encantou e encanta turistas de todas as partes do globo, sendo cenário para inúmeros filmes, novelas e documentários.

Os primeiros relatos sobre o município são do ano de 1536 quando a expedição de Martim de Sá passou pela região com destino ao Vale do Paraíba, buscando aprisionar índios para escravizá-los. Ao longo dos séculos muita coisa mudou e a história pode ser contada através do valiosíssimo patrimônio material e imaterial que compõe o município.

A cidade possui igrejas, casarões e fazendas que remetem ao tempo do Brasil Colônia e que representam importantes atrativos turísticos aliados a mata atlântica, presente em $80 \%$ do município, com trilhas, praias e ilhas em perfeita harmonia.

A convivência integrada entre patrimônio cultural e o natural possibilitou um grande desenvolvimento turístico a partir da década de 80 e atualmente representa $75 \%$ de toda atividade econômica, seguida pela pesca (15\%) e a produção de aguardente e agricultura com $10 \%$.

A partir do Programa de Regionalização do Turismo - Roteiros do Brasil, a cidade foi considerada um dos 65 destinos indutores do desenvolvimento turístico regional, junto com mais quatro cidades do estado do RJ: Angra dos Reis, Armação de Búzios, Petrópolis e Rio de Janeiro. Todos estes destinos

devem ser trabalhados até 2010 para a obtenção do padrão de qualidade internacional, constituindo, assim, modelos de destinos indutores do desenvolvimento regional, sendo essa uma das metas do PNT 200/2010.

Para o Programa de Regionalização do Turismo, os destinos indutores de desenvolvimento turístico regional deverão ser aqueles que possuem infraestrutura básica e turística e atrativos qualificados que se caracterizem como núcleo receptor e/ou distribuidor de fluxos turísticos, isto é, aqueles capazes de atrair e/ou distribuir significado número de turistas para seu entorno e dinamizar a economia do território em que estão inseridos." (PNT, 2007)

Este cenário turístico tem despertado tamanho apoio por empresas, personalidades e grupos não governamentais que em 2008 possibilitou a articulação da cidade em pleitear o 
titulo de patrimônio mundial à UNESCO, visto que desde 1983 a cidade já é considerada patrimônio natural pelo IPHAN.

Uma cidade que "respira" turismo e que tem no calendário de eventos deste ano trinta e seis atividades culturais distribuídas ao longo de 180 dias deve ter como premissa um envolvimento completo da população local e a escola é o local perfeito para o desenvolvimento de cidadãos críticos e agentes multiplicadores diante do fenômeno turístico.

\title{
5.1 - A Educação Turística em Paraty
}

A inserção da disciplina turismo na grade curricular do município contribuirá para consolidar ainda mais o compromisso ético dos alunos com o meio ambiente e com o patrimônio cultural, visto que uma abordagem inter e transdisciplinar possibilitará um maior conhecimento sobre toda a sua riqueza material e imaterial, que formam a identidade cultural da população autóctone.

A preocupação com a identidade local é algo que vem ganhando cada vez maior importância na sociedade visto que

\begin{abstract}
manter algum tipo de identidade étnica, local ou regional parece ser essencial para que as pessoas se sintam seguras, unidas por laços extemporâneos a seus antepassados, a um local, a uma terra, a costumes e hábitos que lhes dão segurança, que lhes informam quem são e de onde vêm, enfim, para que não se percam no turbilhão de informações, mudanças repentinas e quantidade de estímulos que o mundo atual oferece. (BARRETO, 2004, p. 45).
\end{abstract}

A cidade de Paraty possui uma diversificada demonstração de sua cultura como através das exibições de danças típicas, do artesanato de cestaria, dos elementos locais representados em madeira e até mesmo do artesanato dos índios guaranis que vivem no município. Tudo isto agrega valor a idéia de destino turístico cultural.

O turismo cultural tornou-se importante segmento para a cidade com a exibição de danças locais, festivais gastronômicos que valorizam a agricultura e a maricultura local, e festivais literários que enriquecem o contato dos turistas com toda a história local. Além de 
produtos turísticos toda esta diversidade pode complementar de forma grandiosa o aprendizado dos alunos nas aulas do ensino médio.

Atualmente, a cidade conta com três escolas de ensino médio e que possuem condições para apresentar ótimas discussões sobre meio ambiente e pluralidade cultural a partir do amplo acervo cultural e natural do município e permitir uma aproximação das matérias tradicionais como história e geografia. A utilização da diversidade local nas aulas favorece o ensino a partir da experiência dos alunos, como proposto pelo Parâmetro Curricular Nacional. 


\section{METODOLOGIA}

A realização do presente trabalho cientifico tem por objetivo investigar a pertinência da inserção da disciplina turismo como tema transversal no ensino médio do município de Paraty.

A pesquisa foi de forma exploratória, uma vez que visou conhecer de forma mais aprofundada os fatos e os fenômenos relativos ao tema, como exemplos a situação da atual grade curricular das escolas de ensino médio e qual a atual participação dos bens patrimoniais e naturais na elaboração dos conteúdos educacionais. São estudos iniciais que certamente abrem grande espaço para novos assuntos sobre o assunto.

Por se tratar especificamente de uma cidade a finalidade da pesquisa é aplicada, tendo por finalidade uma aplicação prática nas escolas e posteriormente, a medida que novos estudos forem surgindo, incentivadas nas séries do ensino fundamental.

Todo o levantamento das informações da monografia foi feito a partir do recolhimento e da análise bibliográfica de todo o conhecimento já produzido a respeito do tema até o momento. Outra fonte utilizada na coleta de informações foi os alunos e os professores que forneceram opiniões sobre o tema estudado, conforme os apêndices 1 e 2.

A partir das respostas fornecidas nos questionários pelos alunos e pelas informações dos docentes, através da entrevista, considerou-se, por indução que os resultados válidos para a amostra também são aplicáveis a todo o universo. Desta forma a pesquisa assumiu uma natureza qualitativa.

O local da realização do levantamento das informações com as amostras de docentes e discentes foi feito nas próprias três escolas de ensino médio do município. A coleta das informações com os professores foi feita através de entrevistas semi estruturada, gravadas em áudio e de questionário com perguntas fechadas aos alunos. 
O formato de entrevista em áudio com os professores foi escolhido por possibilitar maior liberdade e interação com os entrevistados. As respostas foram ocorrendo de forma espontânea ao longo da pesquisa, o que possibilitou opiniões além das próprias perguntas. A amostra foi composta por nove professores, abrindo para áreas além da geografia e história (relacionadas frequentemente ao turismo) a fim de obter uma visão diferente do que os professores das disciplinas relatadas normalmente possuem. A pesquisa foi aplicada a professores de sociologia, português, história, literatura, biologia e matemática. O formato de questionário com perguntas fechadas para os alunos foi uma forma de obter foco nas respostas e não utilizar muito tempo dos professores que interromperam aulas para a aplicação das perguntas.

As respostas e considerações sobre o levantamento de informações, através dos alunos e professores, seguem no próximo capítulo. 


\section{7 - PESQUISA}

A entrevista com os docentes foi feita utilizando seis perguntas norteadoras e análise das respostas foi feita de forma genérica, seguindo as questões, respostas e considerações:

\section{1 - O que significa turismo para você?}

As respostas a primeira pergunta evidenciam que os professores têm uma visão melhor do que podia se esperar sobre turismo, uma vez que a maioria deu mais de um significado para a atividade, como demonstrado no gráfico 1.

\section{Gráfico 1 - Significado de turismo para docentes}
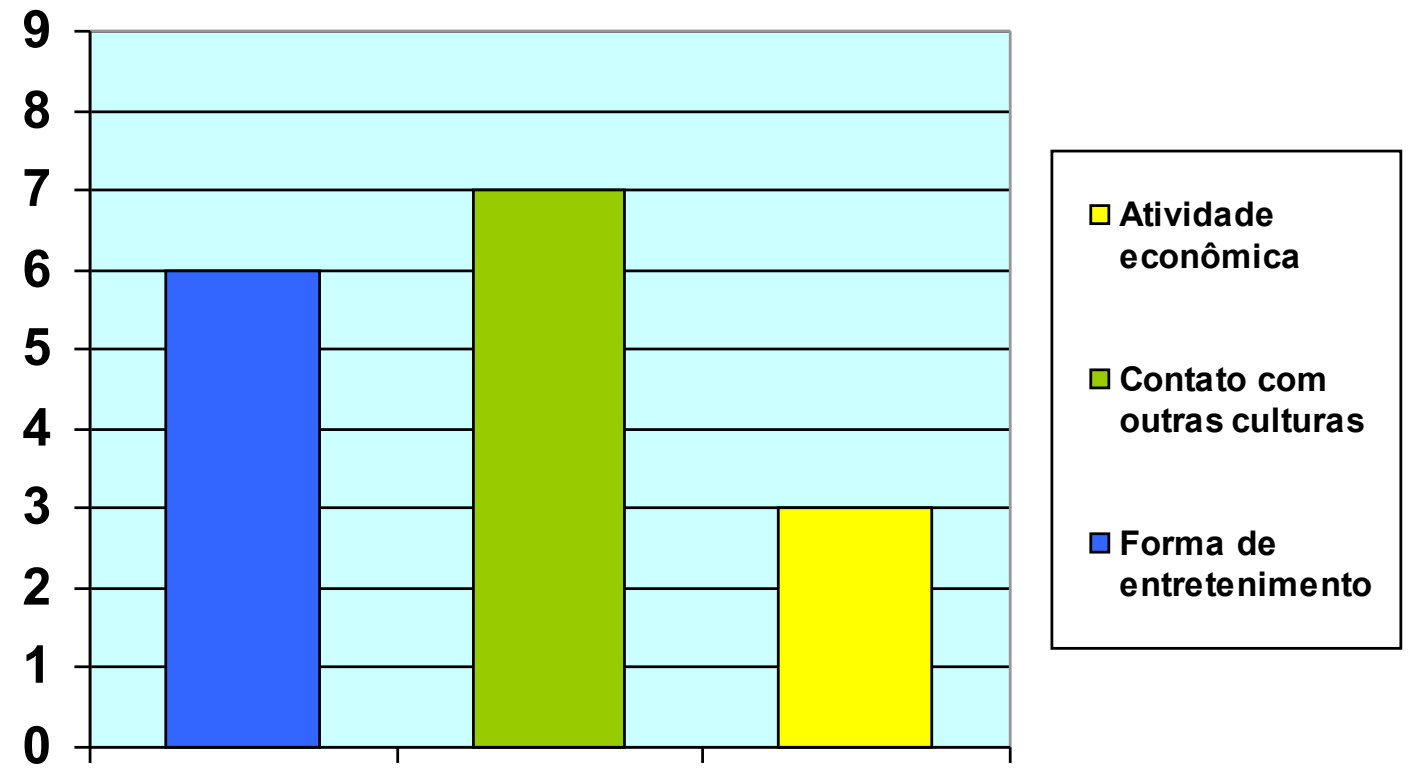

O aspecto cultural aliado ao entretenimento já demonstra uma maturidade dos professores em ir além da simples visita a um destino e da receita gerada durante o tempo de estadia.

Geralmente, o senso comum ainda entende "turismo" apenas como forma de lazer, se concentrando nos atrativos naturais e artificiais de uma localidade. 


\section{2 - Algum aluno já pediu a você para abordar temas turísticos nas aulas?}

Do total de nove professores entrevistados a maioria ainda não teve pedidos dos alunos para abordar questões relacionadas ao turismo na sala de aula,conforme o gráfico 2:

Gráfico 2 - Porcentagem dos alunos que pediram a abordagem de assuntos turísticos
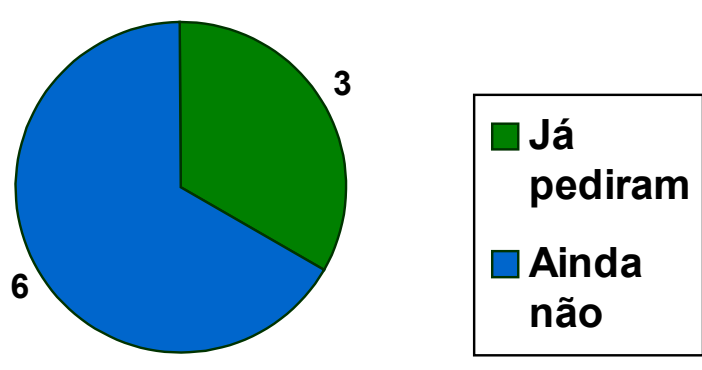

Apesar da maiorıa das respostas ser negatıva, todos os protessores que ainda não utilizaram questões relacionadas ao turismo na sala de aula perceberam o potencial que o fenômeno turístico possui para dinamizar as aulas e despertar um maior interesse e compreensão dos alunos sobre suas disciplinas.

As respostas afirmativas foram da professora de inglês, que utiliza o cotidiano dos alunos como as conversas entre os turistas e a população autóctone para mostrar a importância do aprendizado. Já as professoras de português e sociologia comentam que os pedidos ocorrem em função da necessidade de se apresentarem corretamente aos turistas, visto que alguns são guias turísticos.

Diante disto, vê-se que o pedido dos alunos para abordar questões relacionadas ao turismo ocorre em função da necessidade de se obter um bom relacionamento com os turistas, ou seja, é a forma de incrementar este contato e obter maiores benefícios. 
3 - Você já teve alguma experiência com ações relacionadas ao turismo, meio ambiente e cultura? Quais?

Todos os professores já tiveram algum tipo de experiência relacionadas as atividades de turismo, meio ambiente e até cultural. Os papéis assumidos nessas experiências estão explicitados no gráfico 3, a seguir.

Gráfico 3 - Tipos de ações relacionadas ao Meio Ambiente, Turismo e Cultura

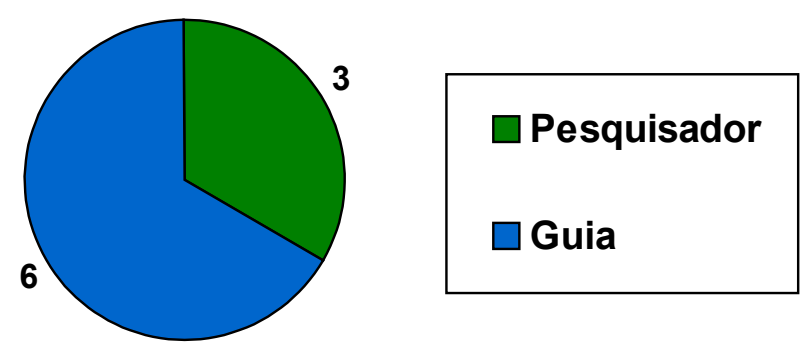

As respostas a essa terceira questão vêm corroborar as reflexões feitas na primeira pergunta. Realmente, todos os professores, por viverem em um dos principais destinos turísticos do Brasil, tiveram alguma experiência em turismo, seja como guia, seja como pesquisador.

Isto aliou estudos de enriquecimento cultural às relações com a natureza, o trabalho e a sociedade. Por outro lado, evidenciou-se que eles se sentem estimulados a promover o envolvimento da população local, principalmente dos alunos e de suas famílias, mostrando que uma adequada recepção de pessoas pode se tornar uma atividade econômica interessante e de retorno imediato. 


\section{4 - Você percebe alguma relação entre a formação do aluno e o turismo no município?}

Todos os professores responderam de forma afirmativa e consideram que o turismo, aliado aos temas transversais, pode enriquecer o diálogo sobre a realidade local, seu conhecimento e até mesmo aumentar as possibilidades de emprego aos alunos.

A falta desta relação faz com o que o aluno não conheça a própria localidade onde vive. Isto pode gerar omissão frente aos seus bens naturais e culturais e o turismo pode ocorrer de forma não sustentável em algumas áreas do município.

Para uma das professoras, esta omissão, que existe em todas as partes do país, é resultado do atual modelo de ensino que se preocupa com as questões globais ao passo que a visão local ainda é muito tímida, quando existe.

\section{5 - Já utilizou algum atrativo do município na elaboração de seu conteúdo educacional?}

\section{De que forma?}

Por ser um município com uma geografia privilegiada e uma riqueza patrimonial muito bem conservada, a maioria dos professores (aproximadamente 78\%) já utilizou algum atrativo para complementar o ensino de algum conteúdo, sendo as principais formas de utilização as descritas no gráfico 4.

\section{Formas que o atrativo foi utilizado}

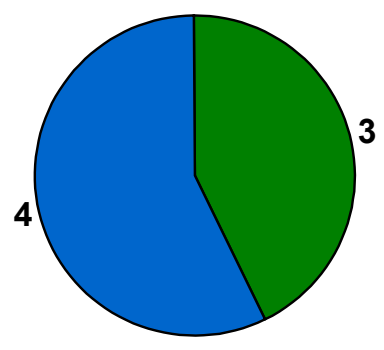


A riqueza cultural e natural do município possibilita uma diversificação na forma de apresentar o conteúdo educacional ao aluno, como exemplo a FLIP (Feira Literária Internacional de Paraty) que, aliada às disciplinas de português e literatura, serve como uma forma mais dinâmica e interessante de apresentar determinado estilo lingüístico e a história de algum artista. O meio ambiente também oferece oportunidade ímpar, como a visita a determinados locais para uma maior interação e conhecimento de determinado aspecto ecológico e geográfico. Além disso, existem os patrimônios materiais e imateriais que podem ser utilizados na aprendizagem de importantes fases da economia brasileira e da história nacional.

As respostas evidenciam que a maioria dos docentes possui uma visão pro ativa na elaboração e aplicação de seus conteúdos, buscando o suporte local, que oferece a chance dos alunos se sentirem mais motivados s e obtenham melhor compreensão daquilo que estudam.

\section{6 - Você acha que a inserção da disciplina turismo na grade curricular do ensino médio} pode contribuir para a formação do aluno? Como?

Todos os docentes entrevistados acham que a disciplina turismo tem muito a contribuir para a formação do aluno. Os principais benefícios apontados na formação estão no gráfico 5:

Gráfico 5 - Contribuição do Turismo para a formação do aluno

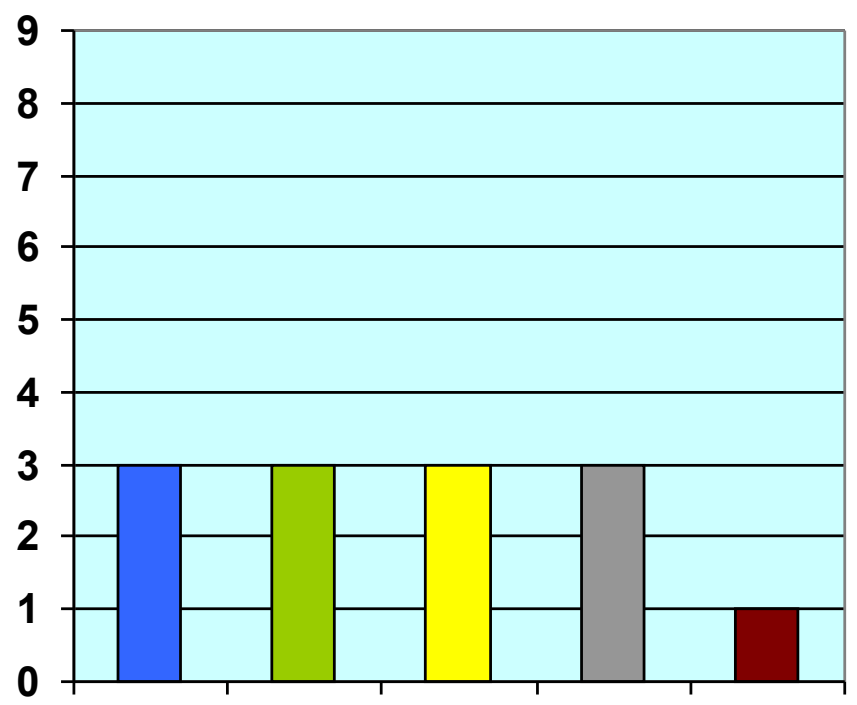

Maior dinamismo nas aulas

$\square$ Oportunidade de emprego

$\square$ Despertar para a preservação local

$\square$ Melhoria na relação com os turistas

$\square$ Conhecimento maior sobre a cultura 
Alguns professores referiram-se a mais de uma resposta. No conjunto eles reconhecem que a atividade turística, aliada com outras disciplinas, pode agregar uma visão mais ampla dos conteúdos apresentados, graças a sua interdisciplinaridade. Os professores percebem a importância dos alunos conhecerem melhor sua cultura Isto contribui para o aumento do sentimento de preservação local e tem reflexos nas formas de tratar o turista, seja passando informações mais seguras, seja contribuindo para uma melhor receptividade e elevação da auto-estima.

Além de contribuir para um maior conhecimento local, a disciplina turismo pode dinamizar as aulas, algo primordial na atualidade, visto que os alunos recebem um grande volume de informação de todos os lugares e muitas escolas ainda se mantêm presa à rotina do "giz e quadro negro". Quanto melhor trabalhado as questões turísticas no município de Paraty, aliado as outras disciplinas, maior a probabilidade do envolvimento dos alunos, que passarão a refletir sobre a forma como o turismo vem sendo desenvolvido no município e até propor formas para maior inclusão da comunidade.

\subsubsection{A Pesquisa com os discentes}

A estruturação da pesquisa com os alunos foi feita a partir de um questionário com perguntas a fim de levantar o perfil sócio-econômico das famílias dos alunos e o que pensam sobre a atividade turística.

A amostra foi composta por quarenta e cinco alunos, em séries diferentes, das três escolas de ensino médio existentes no município de Paraty. A maior parte dos entrevistados foi de alunas, representando $53 \%$ do total.

O grupo estudado compreende uma faixa etária diversificada, desde 15 a 21 anos de idade, distribuindo-se conforme o gráfico abaixo: 


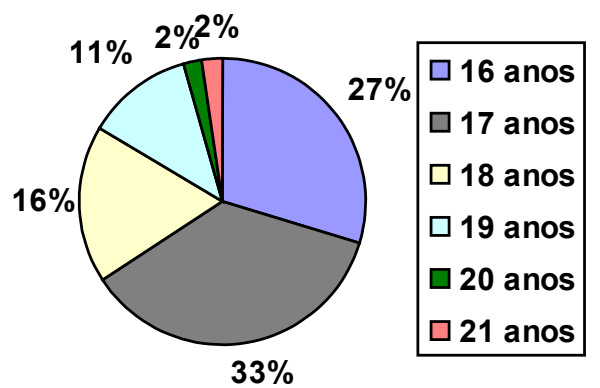

A maior parte dos pais dos alunos entrevistados possui ensino médio. Alguns possuem ensino superior, sendo demonstrado no gráfico 7 :

Gráfico 7- Escolaridade dos pais

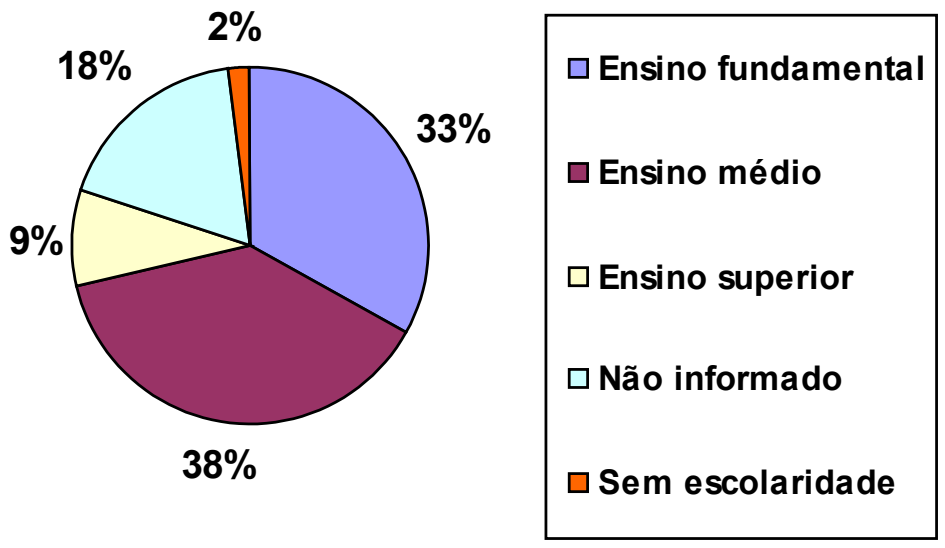

Estes números demonstram que a escolaridade já alcançou um nível considerável no município. A concentração da escolaridade no ensino médio deve-se, em grande parte, à falta de instituições superiores no município.

As mães possuem um grau de escolaridade maior que os pais, inclusive a quantidade que possui ensino superior é acima da média masculina, de acordo com o gráfico a seguir: 


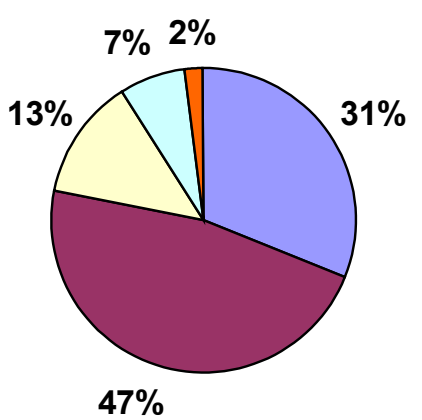

$\square$ Ensino fundamental

¿Ensino médio

$\square$ Ensino superior

$\square$ Não informado

$\square$ Sem escolaridade

Pelo questionário tentou-se identificar o número de alunos que têm familiares trabalhando diretamente e indiretamente na atividade turística. As respostas foram superficiais, o que impossibilitou levantar esta informação.

Para não interromper as aulas durante muito tempo, apesar de ter sido bem recebido em todas as escolas, no questionário aplicado aos alunos optou-se por apenas três perguntas:

1 - O que significa turismo para você?

2 - Acha a atividade importante para a cidade? Por que?

3 - Gostaria de estudar turismo na escola? Por que?

As respostas e considerações estão a seguir.

\section{1 - O que significa turismo para você?}

Pelas respostas, vê-se que os alunos possuem uma visão até madura do que é turismo, visto todo o conhecimento adquirido sobre a atividade ser formulado pelas próprias experiências pessoais. Alguns alunos consideram-no em mais de uma possibilidade de resposta, conforme o gráfico 9. 


\section{Gráfico 9 - Significado de Turismo para discentes}
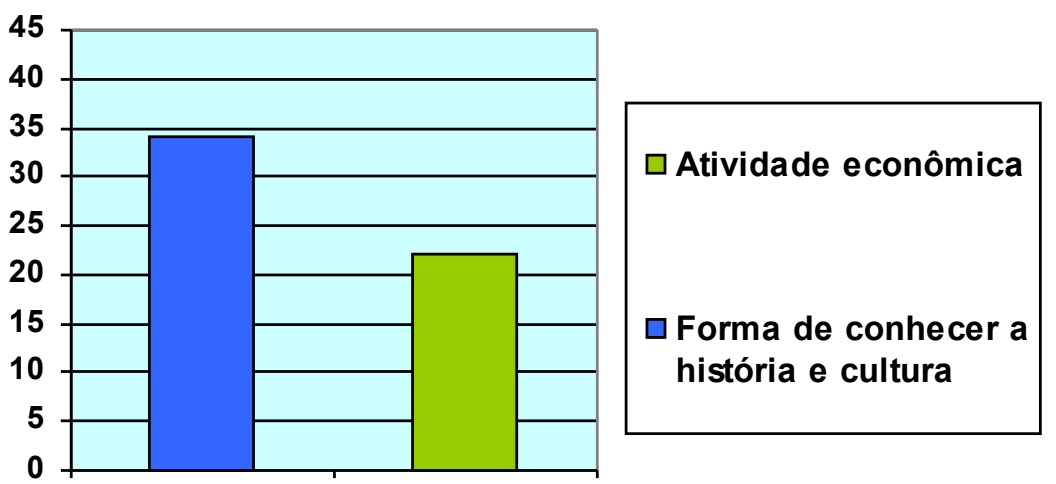

Tal fato pode ser justificado por viverem em uma cidade famosa por todo patrimônio material e imaterial, que despertam a atenção de turistas em busca das belezas locais e, até mesmo, um conhecimento maior sobre a história do país.

A preocupação da maioria dos alunos em conhecer e valorizar os patrimônios demonstra a abertura para a elaboração de atividades que façam uma integração maior entre os bens do município e os alunos, seja através das ações de educação patrimonial e ambiental como também através do planejamento interpretativo.

Como uma parte dos alunos citou a questão econômica do turismo, um trabalho de conscientização, integrado a outras disciplinas, pode apresentar uma grande aceitação dos alunos, que passariam a lutar pela atividade sustentável que garante benefícios também a longo prazo.

\section{2 - Acha a atividade importante para a cidade? Por quê?}

Todos os alunos reconhecem a importância da atividade turística para Paraty, alguns, inclusive, a justificam em termos de mais de um aspecto, conforme o gráfico 10: 


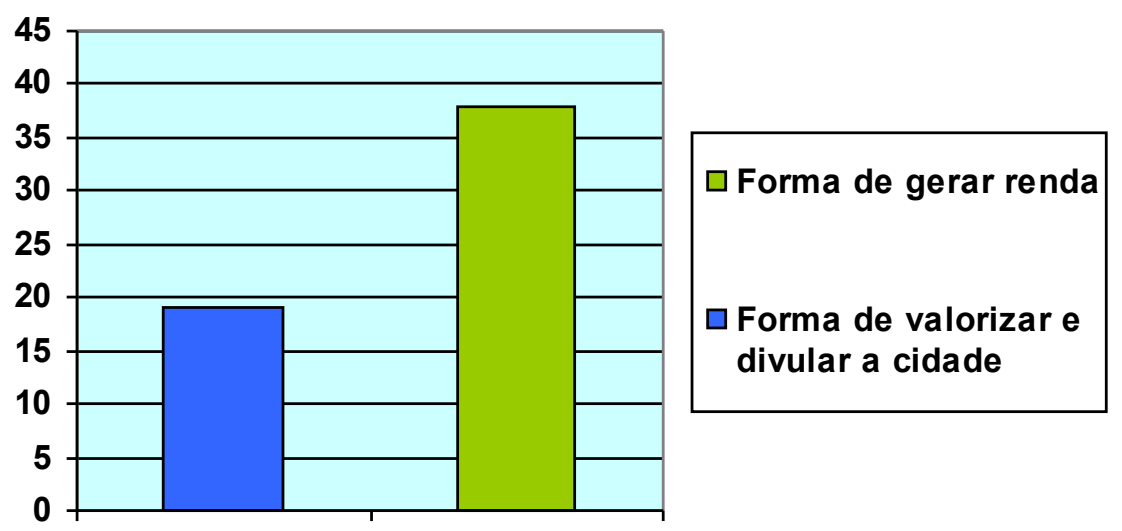

Como vivem em um município que possui atividades econômicas do setor primário e terciário - esta representando quase $80 \%$ do total - os alunos sabem da importância dos visitantes no município, já que praticamente todas as famílias possuem membros ligados diretamente ou indiretamente à atividade.

\section{3 - Gostaria de estudar turismo na escola? Por quê?}

A grande maioria dos alunos $(91 \%$ da amostra) é a favor deste estudo. Uma minoria (9\%) não gostaria de ter aulas sobre turismo.

Quanto ao interesse pelo estudo do turismo, alguns alunos falaram que a inserção da disciplina pode contribuir de diversas formas, conforme demonstrado no gráfico 11

\section{Gráfico 12 - Motivo do interesse}

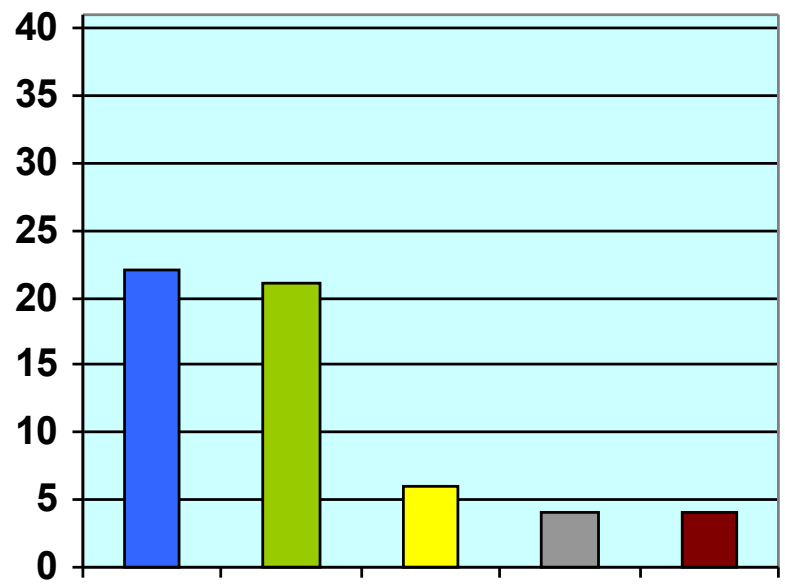

Nâo precisar sair para estudar fora

$\square$ Dinamizar as aulas

$\square$ Entender melhor a atividade

$\square$ Oportunidade de emprego

Maior conhecim ento sobre a cidade 
O elevado número de alunos que gostaria de estudar turismo na escola é a evidência de que o turismo merece tratamento privilegiado nas escolas. A inserção da disciplina turismo como tema transversal no ensino médio é um estimulo ao conhecimento maior sobre a cidade e pode apresentar reflexos diretos no modo dos alunos se comportarem como cidadãos.

As oportunidades de emprego também aumentam, uma vez que passam a estar mais capacitados a lidar com os turistas, seja na parte do planejamento das atividades locais como também no contato direto com os visitantes.

Alguns alunos vêem a possibilidade de um maior entendimento sobre este fenômeno e, até mesmo, aprofundar seus estudos, o que pode contribuir para o debate turístico, que está em crescente processo, e nas formulações de políticas públicas e planejamento de atividades locais.

A disciplina turismo, como tema transversal no ensino médio, pode contribuir para a realização de aulas mais dinâmicas, visto que as possibilidades de aliar a atividade turística aos conteúdos programáticos de outras disciplinas são enormes e certamente possibilitaria uma compreensão maior dos conteúdos.

Todos os alunos que não são a favor da inserção da disciplina na grade curricular possuem interesses em outras áreas de estudo, como por exemplo, educação física.

Diante da análise das respostas conclui-se que os alunos entrevistados possuem certo grau de maturidade diante do fenômeno turístico e, para eles, a aproximação entre o conteúdo escolar e experiências pessoais possibilita um conhecimento mais profundo, uma visão mais interessante onde o aluno passaria do estado de simples curiosidade à curiosidade epistemológica que Freire (2002, p. 15 ) considera como "uma inquietação indagadora, como inclinação ao desvelamento de algo e como sinal de atenção que sugere alerta". Ou seja, é um 
processo que pode incentivar o aluno a uma curiosidade crescente, que pode torná-lo cada vez mais formulador de questões e solução em sua comunidade.

Indubitavelmente é necessário um conhecimento maior dos alunos sobre sua identidade a fim de entender porque determinado elemento passou a ter representatividade, como foi criado, qual era a sua finalidade e qual a sua relação com o futuro. Todo este descobrimento possibilita um jogo de afirmações e negativas que vão (re) construindo a identidade do povo Paratiense.

A inserção da disciplina turismo como tema transversal no ensino médio de Paraty deve ser formulada a partir da participação da população, instituições de ensino, turismólogos e até através de parcerias com prefeituras que já vivenciam esta pratica pedagógica, como ocorre em Angra dos Reis. 


\section{8 - CONCLUSÃO}

O trabalho procurou demonstrar que a atividade turística pode ser importante aliada no processo educacional no município de Paraty. Tal fato pode ser observado por meio da pesquisa com os alunos e professores, onde a grande maioria já possui uma visão madura da atividade, reconhece a importância da atividade e percebe como pode contribuir para o ensino do município.

A inserção da disciplina turismo como tema transversal no ensino médio contribui para que os alunos conheçam, compreendam, respeitem e até divulguem de melhor forma toda a sua riqueza cultural e natural. Com isso, a inserção da disciplina é algo pertinente e urgente, visto que é uma forma de consolidar o compromisso ético dos alunos com o meio ambiente e com o patrimônio cultural.

Uma cidade que é considerada um dos principais destinos indutores da atividade turística no país deve ter o foco na qualidade de seus produtos e na melhor qualidade de vida para a sua população, o que não pode ser obtido apenas através de investimentos em infraestrutura. A qualidade de vida da população autóctone também passa pelo ambiente escolar.

A escola é o local onde a consciência critica, a criatividade e o senso de cidadania devem ser incentivados para despertar nos alunos, e consequentemente na sociedade, novas formas de lidar com seus bens e com os turistas.

O turismo vem se desenvolvendo gradativamente e seus impactos começam a ser discutidos pela sociedade e nas instituições de ensino, onde muitas escolas já inseriram a disciplina na sua grade para estabelecer melhor compreensão e participação neste processo tão importante na sociedade moderna.

Muitas escolas de outras cidades já fazem visitas a Paraty como forma de enriquecer os conteúdos abordados em sala de aula, algo que ainda ocorre de forma tímida nas próprias escolas locais. Além de contribuir para um melhor entendimento, a interação entre a disciplina 
turismo e outras disciplinas pode gerar aulas mais dinâmicas e um aprofundamento maior dos temas, onde os alunos se sentiriam mais motivados e passariam a compreender como os assuntos abordados em sala possuem relação com seu cotidiano.

O ensino todo turismo não reflete apenas na população autóctone, uma vez que a disciplina pode contribuir para que os próprios turistas tenham maior respeito sobre o que está sendo visitado, diminuindo os erros de comportamento (ainda comuns em diversos destinos) e um sentimento mais humano, deixando de ver a localidade e a população como um simples local que possui meros empregados a disposição.

O Ministério da Educação, através dos PCN's reconhece a importância de abordar questões locais, até pela necessidade de atualizar a educação brasileira, e certamente a partir do momento que os alunos de Paraty relacionarem os conteúdos educacionais com seu cotidiano haverá melhor utilização dos bens culturais e naturais e maiores oportunidades de emprego, com reflexos nas atitudes perante os turistas em um desenvolvimento de produto turístico competitivo e acima de tudo sustentável. 


\section{REFERÊNCIAS BIBLIOGRÁFICAS E OUTRAS}

ALMEIDA, Regina Araújo, et al. Caminhos do Futuro. 1 ed. São Paulo: IPSIS, 2007.

ANDRADE, José Vicente de Andrade. Turismo - Fundamentos e dimensões. 8 ed. São Paulo: Ática, 2004.

BARRETTO, Margarida. Turismo e legado cultural. 2 ed. Campinas: Papirus, 2002.

BERNARDI, Pedro Antonio. Ensino Fragmentado cria fendas na mente dos alunos. Disponível em http://www.futuroeventos.com.br/noticias/main/integra?noticia_id=389. Acesso em 27/03/2009.

CARLOS, Jairo Gonçalves. Interdisciplinaridade no Ensino Médio: desafios e potencialidades. Brasília, 2007, 172 p. Dissertação de Mestrado. Mestrado Profissionalizante em Ensino de Ciências Universidade de Brasília. .

DIAS, Reinaldo. Sociologia do Turismo. 2 ed. São Paulo: Atlas, 2003.

DELORS, Jacques. Educação: Um tesouro a descobrir. 3.ed. São Paulo: Cortez, 1999.

FREIRE, Paulo. Pedagogia da autonomia: saberes necessários a prática educativa. 25 ed. São Paulo: Paz e Terra, 2002.

FILHO, Ari da Silva Fonseca. Educação e Turismo: Um estudo sobre a inserção da disciplina turismo no ensino Fundamental e Médio. São Paulo, 2007. 183 p. Dissertação de Mestrado em Educação. Faculdade de Educação, Universidade de São Paulo.

HORTA, Maria de Lourdes Parreiras Horta. Guia básico de educação patrimonial. 1 ed. Petrópolis: IPHAN; Museu Imperial, 1999.

IBGE. Projeção da População do Brasil por Sexo e Idade - 1980-2050 - Revisão 2008

Disponível em: http://www.ibge.gov.br/home/estatistica/populacao/projecao_da_populacao/2008/default.shtm Acesso 01 de Maio de 2009.

LUCKESI, Cipriano Carlos. Filosofia da educação. São Paulo: Cortez, 1993.

MINISTÉRIO DA EDUCAÇÃO. Apresentação dos temas transversais. - Brasília: MEC/SEF, 1998.

PCN + Ensino Médio: Orientações Educacionais complementares aos Parâmetros Curriculares Nacionais. Brasília: SEMTEC, 20022002

MINISTÉRIO DO TURISMO. Plano Nacional do Turismo e Programa de Regionalização do Turismo - Roteiros do Brasil, 2007. 
MORIN, Edgar. A cabeça bem feita: Repensar a reforma, reformar o pensamento. 8 ed. Bertrand Brasil. 2003.

Unesco, 2000.

Os sete saberes necessários à educação do futuro. 2 ed. São Paulo:

MURTA, Stela Maria; ALBANO, Celina. Interpretar o patrimônio: um exercício do olhar. 2. ed. Belo Horizonte: Território Brasilis, 2005.

PELIANO, José Carlos Pereira. A importância da educação para o novo modo de produção do conhecimento. Disponível em http://www.pt.org.br/assessor/mecunb.htm. Acesso em 29 mar. 2009.

POMBO, Olga; LEVY, Tereza; GUIMARÃES, Henrique. A Interdisciplinaridade: Reflexão e Experiência. 2 ed. Lisboa: Texto, 1994.

REJOWSKI, Mirian. Turismo e Pesquisa Científica. 7 ed. Campinas: Papirus, 2003.

SEBRAE. Disponível em

www.agenciasebrae.com.br/noticia.kmf?noticia $=8047954 \&$ canal $=36 \&$ total $=80999 \&$ indice $=10$

Acesso 03 mai 2009.

TRIGO, Luiz Gonzaga Godoi. A sociedade pós-industrial e o profissional em turismo. 6 ed. Campinas, SP: Papirus, 2002. 
APENDICES 


\section{APENDICE 1}

\section{PERGUNTAS DA ENTREVISTA COM OS DOCENTES}

1 - O que significa turismo para você?

2 - Algum aluno já pediu a você para abordar temas turísticos nas aulas?

3 - Você já teve alguma experiência com ações relacionadas ao turismo, meio ambiente e cultura? Quais?

4 - Você percebe alguma relação entre a formação do aluno e o turismo no município?

5 - Já utilizou algum atrativo turístico do município na elaboração de seu conteúdo educacional? De que forma?

6 - Você acha que a inserção da disciplina turismo na grade curricular do ensino médioa pode contribuir para a formação do aluno? Como? 
APENDICE 2

\section{QUESTIONÁRIO COM OS DISCENTES}

Sexo: $\mathrm{M}$

Idade:

Profissão do pai:

Profissão da mãe:

Escolaridade do pai: s/ escolaridade ensino fundamental ensino médio ensino superior

Escolaridade da mãe: s/ escolaridade ensino fundamental ensino médio ensino superior

1. O que significa turismo para você?

2. Acha a atividade turística importante para a cidade? Por quê?

3. Você gostaria de estudar turismo na escola? Por quê? 